\title{
INNOVATION AND TECHNOLOGIES: SUCCESS FACTORS IN ADMINISTRATION OF ORGANIZATIONS WITH DEVELOPMENT AND COMPETITIVENESS
}

\author{
INOVAÇÃO E TECNOLOGIAS: FATORES DE ÊXITO NA GESTÃO DAS ORGANIZAÇÕES \\ COM DESENVOLVIMENTO E COMPETITIVIDADE
}

\author{
INNOVACIÓN Y TECNOLOGÍA: FACTORES DE ÉXITO EN LA GESTIÓN DE \\ ORGANIZACIONES CON DESARROLLO Y COMPETITIVIDAD
}

Ilmar Polary Pereira ${ }^{1}$

\section{Cite as - American Psychological Association (APA)}

Pereira, I. P. (2021, Jan./Apr.). Innovation and technologies: success factors in administration of organizations with development and competitiveness. International Journal of Innovation - IJI, São Paulo, 9(1), 180-214.

https://doi.org/10.5585/iji.v9i1.18400.

\begin{abstract}
Objective: This article analyzes the innovation, management technologies and the dimensions and components of technological capacity as success factors and perennity in micro and small companies and organizational excellence in public organizations.

Methodology/Approach: Data were extracted from secondary sources in the literature. In the field, the universe was of 1.700 industrial companies, 15.112 of service delivery companies, 16 hospitals and 03 universities, with stratified random samples and for accessibility. The data received statistical treatment: descriptive analysis, levene test of homogeneity of variances and variance analysis, correlation test, regression, and multiple correlation.

Originality/Relevance: Integrated sustainability administration model, as a management technology, emerges as an innovation alternative for private and public organizations, which, together with the dimensions and components of technological capacity, expands the perspectives of organizational development and market competitiveness.

Main results: In the empirical analysis, it suggests that innovation and management technologies combined with the competent dimensions of technological capacity, favor organizational development, the success and perennity of micro and small industrial and service delivery companies, and organizational excellence in public organizations.

Theoretical/methodological contributions: This study contributes to literature of innovation field, management technologies, dimensions, and components of technological capacity to academia.

Social/management contributions: The use of management technologies combined with the dimensions and components of technological capacity in micro and small industrial companies and public organizations, impacts on sustainable management and social development.
\end{abstract}

Keywords: Innovation. Technologies. Integrated sustainability administration. Micro and small companies. Public organizations.

\footnotetext{
${ }^{1}$ Doctor, Brazilian School of Public and Business Administration - Getulio Vargas Foundation EBAPE-FGV. Rio de Janeiro - Brazil. i.polary@ hotmail.com
} 


\section{Resumo}

Objetivo: Analisar a inovação, as tecnologias de gestão e as dimensões e componentes da capacidade tecnológica como fatores de sucesso e perenidade nas micro e pequenas empresas e excelência organizacional nas organizações públicas.

Metodologia/Abordagem: Os dados foram extraídos das fontes secundárias na literatura. No campo, o universo foi de 1.700 micro e pequenas empresas industriais, 15.112 de prestação de serviços, 16 hospitais e 03 universidades, com amostras aleatória estratificada e por acessibilidade. Os dados receberam tratamento estatístico: análise descritiva, teste de levene de homogeneidade das variâncias e análise da variância, teste de correlação, regressão e correlação múltipla.

Originalidade/Relevância: O modelo da gestão por sustentabilidade integrada, como uma tecnologia de gestão, emerge como uma alternativa de inovação para as organizações privadas e públicas, que aliada às dimensões e componentes da capacidade tecnológica, ampliam as perspectivas de desenvolvimento organizacional e competitividade de mercado.

Principais resultados: Na análise empírica, sugere que a inovação e as tecnologias de gestão aliada às dimensões e competentes da capacidade tecnológica, favorecem o desenvolvimento organizacional, o sucesso e a perenidade das micro e pequenas empresas industriais e de prestação de serviços, e a excelência organizacional nas organizações públicas.

Contribuições teóricas/metodológicas: Contribui para a literatura no campo da inovação, das tecnologias de gestão, das dimensões e componentes da capacidade tecnológica e para a academia.

Contribuições sociais/gerenciais: $\mathrm{O}$ uso de tecnologias de gestão aliadas às dimensões e componentes da capacidade tecnológica nas micro e pequenas empresas industriais e organizações públicas, impactam no desenvolvimento gerencial e social sustentável.

Palavras-chave: Inovação. Tecnologias. Gestão por sustentabilidade integrada. Micro e pequenas empresas. Organizações Púbicas.

\section{Resumen}

Objetivo: Analizar la innovación, las tecnologías de gestión y las dimensiones y componentes de la capacidad tecnológica como factores de éxito y continuidad en las micro y pequeñas empresas y excelencia organizacional en las organizaciones públicas.

Metodología/Abordaje: Datos han sido extraídos de fuentes secundarias en la literatura. En campo, el universo fue de 1.700 micro y pequeñas empresas industriales, 15.112 de prestación de servicios, 16 hospitales y 03 universidades, con muestras aleatorias estratificadas por accesibilidad. Los datos recibieron tratamiento estadístico: análisis descriptivo, Prueba Levene de homogeneidad de varianzas y análisis de varianza, prueba de correlación, regresión y correlación múltiple.

Originalidad/Relevancia: El modelo de gestión integrada de la sostenibilidad, como tecnología de gestión, surge como una alternativa de innovación para las organizaciones públicas y privadas, que, aliada con las dimensiones y componentes de la capacidad tecnológica, amplían las perspectivas de desarrollo organizacional y competitividad del mercado.

Principales resultados: El análisis empírico sugiere que las tecnologías de innovación y gestión, combinadas con las dimensiones competentes de la capacidad tecnológica, favorecen al desarrollo organizacional, al éxito y a la continuidad de las micro y de las pequeñas empresas industriales y de prestación de servicios, así como a la estructura organizacional de excelencia en los organismos públicos.

Aportes teórico-metodológicos: Contribuye a la bibliografía con respecto al campo de la innovación, tecnologías de gestión, dimensiones y componentes de la capacidad tecnológica, así como a la academia. Contribuciones sociales/gerenciales: El uso de tecnologías de gestión combinadas con las dimensiones y componentes de la capacidad tecnológica en las micro y pequeñas empresas industriales y organizaciones públicas, impactan en el desarrollo de la gestión y social sostenible.

Palabras clave: Innovación. Tecnologías. Gestión integrada de la sostenibilidad. Micro y pequeñas empresas. Organización pública. 


\section{Introduction}

Analyzing innovation, dimensions and components of technological capacity and management technologies in the results of micro and small industrial companies (MSCs) and service delivery ones with investigations that seek alternatives to manage problems related to the Technological Administrative, Institutional Political, and Social Economic dimensions and their respective components and variables of the Integrated Sustainability Administration model (ISA), suggests the discovery of other relevant factors in their academic aspects and management practices that can benefit these organizations and their clients, academia and society.

A research problem requires the investigator to be involved in the reality of the situation to be clarified, in which the question that the scientist wishes to clarify may indicate, among the variables, relations of associations (Triviños, 2009). According to Quivy and Campenhoudt (1995, p. 16), "the hypothesis can present itself as an anticipation of a relationship, a phenomenon and a concept capable of explaining it". In accordance with Triviños (2009, p. 105), "the hypothesis arises after the problem formulation, in which the researcher envisages probable solutions and involves a possible truth, in which the facts may or may not verify the hypothesis".

Based on these assumptions, this study fostered the problem: what is the association among innovation, dimensions and components of technological capacity and management technologies, with success and perennity of MSCs and organizational excellence of public organizations?". It also sought for answers for the questions: In which way the ISA application model in industrial MSCs and public organizations of the samples, impact in their results? Is there any association between perennity of Industrial MSCs and economic development? Thus, the following hypothesis was proposed: innovation, dimensions and components of technological capacity and management technologies impact in organizational development, in the success and perennity of micro and small companies and favor the organizational excellence of public organizations.

This article aimed to analyze innovation, management technologies and the dimensions and components of technological capacity as success factors and perennity in micro and small companies and organizational excellence in public organizations. The development was done through bibliographic and field research. 


\section{Theoretical reference}

Among the factors of organizational development, success and perennity of MSCs and organizational excellence of public organizations, innovation, the components of technological capacity and management technologies play an important role, covering various areas of organizational development over the past decades, and these dimensions and components have also diversified.

Technology means the set of knowledge plots - both "practical" (concrete problems and devices), and "theoretical" (but practically applicable) of know-how, methods, procedures, successful and unsuccessful experiences and of course, physical devices and equipment (Dosi, 2006). Technological competence refers to the company skills to carry out innovative activities in products, processes and production organization, organizational systems, equipment, and engineering of stored projects, not only in people's minds (skills, experience, formal qualifications), but also, in its organizational system, routines and procedures (Bell and Pavitt, 1995; Figueiredo, 2003).

Technological capacity at organizational level is the set of resources that can be tangible, coded, or intangible, tacit, codable and non-codable, incorporated in different dimensions of the organization: management and production techniques, organizational routines, organizational structures, values, and norms (Penrose, 1959; Teece \& Pisano, 1994; Figueiredo, 2004; Nelson \& Winter, 2005). Technological capacity is stored, accumulated, in at least 04 components (Lall, 1992; Bell and Pavitt, 1995; Figueiredo, 2003), according to figure 1:

Figure 1 - Visualization of the technological trajectory of developing economy companies

\section{Physical system, database, software, machinery and equipment}

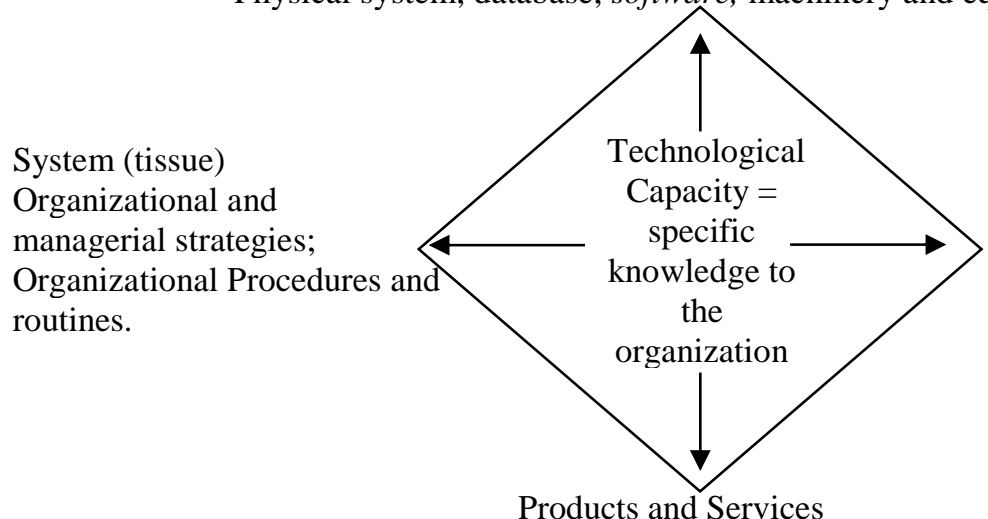

Products and Services

Source: Lall (1992), Bell and Pavitt (1995) and Figueiredo (2003)
Individuals minds tacit knowledge and formal qualification of engineers and technicians, operators. Their experience and accumulated talent. 
Innovation, according to Kim (2005), is a pioneering activity based mainly on the internal competencies of a company to develop and induce a new product in the market. In the Schumpeterian view it is not restricted to products and processes, it involves new forms of management, new markets, and production inputs. It is cumulative.

In studies on Information Technology (IT) investments in MSCs, Oliveira et al. (2014), describe that they are still scarce. In their analyses, there are three factors for IT investment decision: "Usefulness of the Information System"; "Competition Intensity"; and "Partnerships in IT Deployment". In the managerial field, these results allow us to propose factors to be used when interest and demand for IT investments in the MSCs, making it possible to compare the benefits of IT through the correlation between the weight of each factor and the perceived returns.

Regarding to the adoption of IT and its relationship with business management in MSCs, Lunardi et al. (2017), conducted studies to show associations between IT and administrative activities carried out in the various functional areas of the MSCs, and also highlighted certain studies on IT in the MSCs. Among the results, they identified significant differences in the profile of companies that use IT, as well as in the management of their businesses, when compared with those that do not use IT.

The survey was conducted at a time when Brazil stood out positively on the world stage in terms of entrepreneurship. As technologies are becoming more affordable, the importance of studies that contribute to the understanding of adoption and the potential for using the IT by the MSCs, and the majority of service providers already have some type of technology. As for the profile of the owner, it was identified that those of the computerized companies have more educational background than those of the companies without IT, in a number four times higher among those with undergraduate and graduate degrees (Lunardi et al., 2017).

Technological Capacity is incorporated in several dimensions of the organization, including management techniques, highlighting Administration and Professional Management, in the form of administration and the management term described by Drucker (2002). It is Professional and Sustainable Management, as one of the technological capabilities at the organizational level.

In the performance of the Professional Administration for the MSCs, Polary (2012) emphasizes the importance of the analysis of the creation, maintenance, continuous maintenance, growth and perennity, of success processes, planned discharge, failure and mortality, and application of the Integrated Sustainability Administration model (ISA), based 
on the Theory of Entrepreneurship in the following approaches: managerial, McClelland and Winter (1970), posteriorly to the Theories of the Organizations and Administration, in the perspective of the strategies of the companies, and manners of strategic administration, Lumpkin and Dess (1996); and the economical ones, Schumpeter (1934), introduced in Social Sciences by Economic Theory. The ISA model was applied to MSCs in the industrial sample of Maranhao in 2012. In 2014, the model was adapted for public organizations, as shown in tables 1 and 2.

Table 1 - The ISA model integrates 03 dimensions, 05 components and 12 variables

\begin{tabular}{|c|c|c|c|}
\hline Model & Dimensions & Components & Variables \\
\hline \multirow{12}{*}{ ISA } & \multirow{4}{*}{$\begin{array}{l}\text { Technological } \\
\text { Administrative }\end{array}$} & \multirow[t]{2}{*}{ Administration } & $\begin{array}{l}\text { Competencies and Managerial Abilities - professional } \\
\text { management -ISA, based on Entrepreneurship. }\end{array}$ \\
\hline & & & Feasibility studies: technical, economic and financial. \\
\hline & & \multirow[t]{2}{*}{ Technology } & $\begin{array}{l}\text { Technological Support (machinery and equipment; } \\
\text { systems and working methods). }\end{array}$ \\
\hline & & & Industrial efficiency level. \\
\hline & \multirow{4}{*}{$\begin{array}{l}\text { Institutional } \\
\text { Politician }\end{array}$} & \multirow[t]{2}{*}{ Policies } & $\begin{array}{l}\text { Public Policies of the Federal, State and Municipal } \\
\text { Government. }\end{array}$ \\
\hline & & & Legal, fiscal and labor aspects. \\
\hline & & \multirow[t]{2}{*}{ Strategies } & $\begin{array}{l}\text { Local strategies and Institutional Political Partnerships, } \\
\text { Industrial Segment and Civil Society. }\end{array}$ \\
\hline & & & Industrial Development Plan (PDI) -2020. \\
\hline & \multirow{4}{*}{ Economic Social } & \multirow{4}{*}{$\begin{array}{l}\text { Economic and } \\
\text { Social Indicators }\end{array}$} & Qualified industrial labor work. \\
\hline & & & $\begin{array}{l}\text { Investment attractions: internal, external and local } \\
\text { government. }\end{array}$ \\
\hline & & & Preservation of the industry's local environment. \\
\hline & & & \\
\hline
\end{tabular}

Source: Polary (2012).

Table 2 - The ISA model integrates 03 dimensions, 05 components and 12 variables

\begin{tabular}{|c|c|c|c|}
\hline Model & Dimensions & Components & Variables \\
\hline \multirow{12}{*}{ ISA } & \multirow{4}{*}{$\begin{array}{l}\text { Technological } \\
\text { Administrative }\end{array}$} & \multirow[t]{2}{*}{ Administration } & $\begin{array}{l}\text { Competencies and Managerial Abilities - professional } \\
\text { management - ISA. }\end{array}$ \\
\hline & & & Feasibility studies: technical, political, social and financial \\
\hline & & \multirow{2}{*}{ Technology } & $\begin{array}{l}\text { Technological Support (machinery and equipment; systems } \\
\text { and working methods). }\end{array}$ \\
\hline & & & Level of efficiency and effectiveness of results. \\
\hline & \multirow{4}{*}{$\begin{array}{l}\text { Institutional } \\
\text { Politician }\end{array}$} & \multirow{2}{*}{ Policies } & $\begin{array}{l}\text { Public Policies of the Federal, State and Municipal } \\
\text { Government. }\end{array}$ \\
\hline & & & Legality, control and transparency. \\
\hline & & \multirow[t]{2}{*}{ Strategies } & $\begin{array}{l}\text { Partnerships: Institutional Politician, Public-Private and Civil } \\
\text { Society. }\end{array}$ \\
\hline & & & Institutional and Managerial Public Development. \\
\hline & \multirow{4}{*}{$\begin{array}{l}\text { Economic } \\
\text { Social }\end{array}$} & \multirow{4}{*}{$\begin{array}{l}\text { Economic and } \\
\text { Social } \\
\text { Indicators }\end{array}$} & Qualification, performance and results of civil servants. \\
\hline & & & Fundraising: internal and external. \\
\hline & & & Environmental Sustainability. \\
\hline & & & Relevance to society. \\
\hline
\end{tabular}

Source: Polary (2014).

The ISA is an alternative model of Professional Management for the Administration, which requires from the manager professional personal, awareness to manage with 
Entrepreneurial Orientation (EO) and Integrative Vision (IV), beyond its variables, components and dimensions, to favor management, success and perennity of the company.

The theory of Entrepreneurship that founded the ISA model, has its importance for the economy of the countries. Entrepreneurship teaching began in the United States in 1947 at the Harvard School of Business (Katz, 2003). For Schumpeter (1934), it is a process of "creative destruction". According to Dornelas (2008), an entrepreneur is the one who detects an opportunity and creates a business, assuming calculated risks. Baggio and Baggio (2014) affirm that the entrepreneur has the initiative to create a new business and to have passion for what he does.

In an analysis of the world and Brazilian panorama of entrepreneurship, Global Entrepreneurship Monitor (GEM) (Greco, 2008; 2010), show that the Rate of Entrepreneurs in Early Stage (REA) of Brazil in 2008 occupied 13th position in the world ranking. From 2014 to 2015 , Brazil went from 13th to 8th place in the 31 countries of economies driven by efficiency, with REA of 17,2\% in 2014 and 21,0\% in 2015, the highest in the group, surpassing Brazil, Russia, India, China and South Africa countries (BRICs), the United States and Germany.

In 2019, it is observed that REA (developing and new companies), exceeded the Established Entrepreneurship Rate (EER). There is also a major difference in the rates of the two stages (7,1 percentage points), REA having achieved its greatest mark (23,3\%) in 2019. EER, on the other hand has lowered $(16,2 \%)$, returning to the values obtained in $2016(16,9 \%)$ and 2017 (16.5\%), and that in 2018, was 20,2 \%, as shown in figure 2 (GEM, 2019).

Figure 2 - Rates $^{1}$ (in \%) of entrepreneurship according to second stage of REA, EER, TTE enterprise - Brazil - 2002:2019

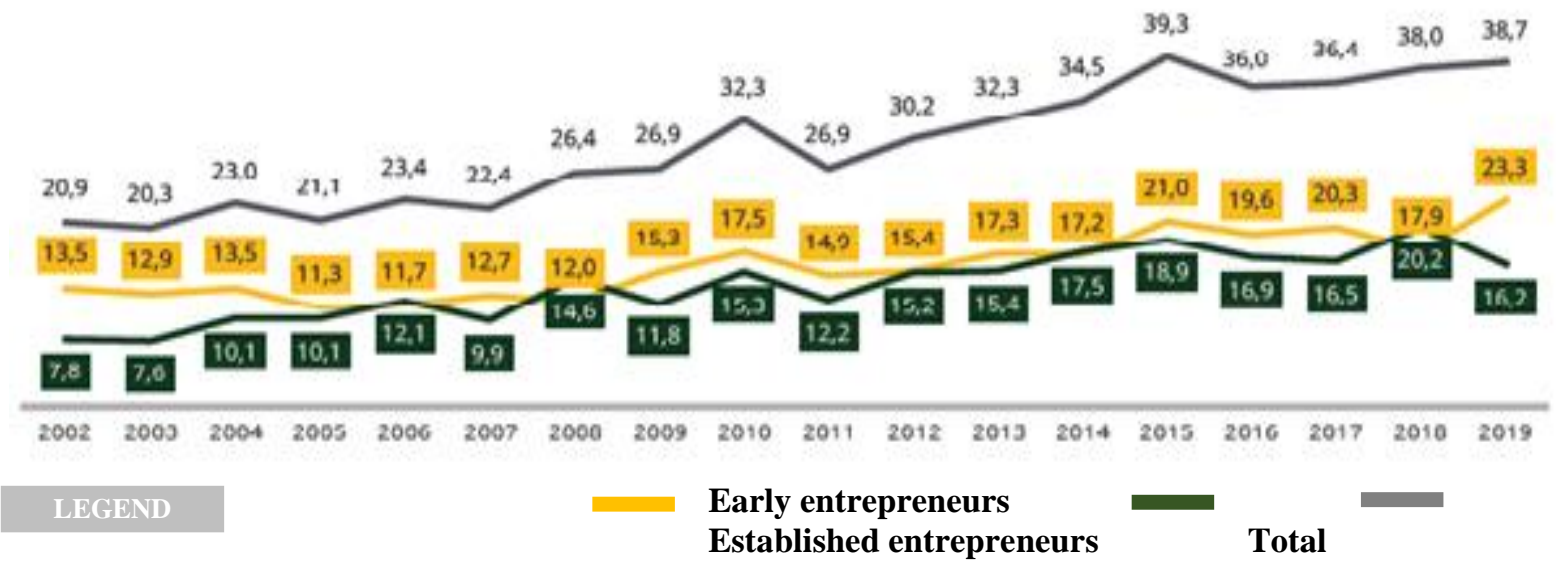

Note: ${ }^{1}$ Percentage of the population aged from 18 to 64 years.

Source: GEM (2019). 
As for levels of development, the highest rates of EER are concentrated in the group of countries driven by factors and the lowest of countries by innovation. Related to GEM study, in partnership with the World Economic Forum 2015, the existence of a negative correlation between the level of development of the countries was identified (factors, efficiency and innovation) and the rates of initial entrepreneurship (REA). Thus, it suggests a better analysis of the variables in this context by the managers, when making their investment decisions in the countries. GEM (2019) presents distinctive aspects, emphasizing the importance of its results for the formulation of policies and programs to support the creation and development of new enterprises, as shown in the figure 3.

Figure 3 - The entrepreneurial process according to definitions adopted by GEM 2019 ENTREPRENEURIAL CONTEXT

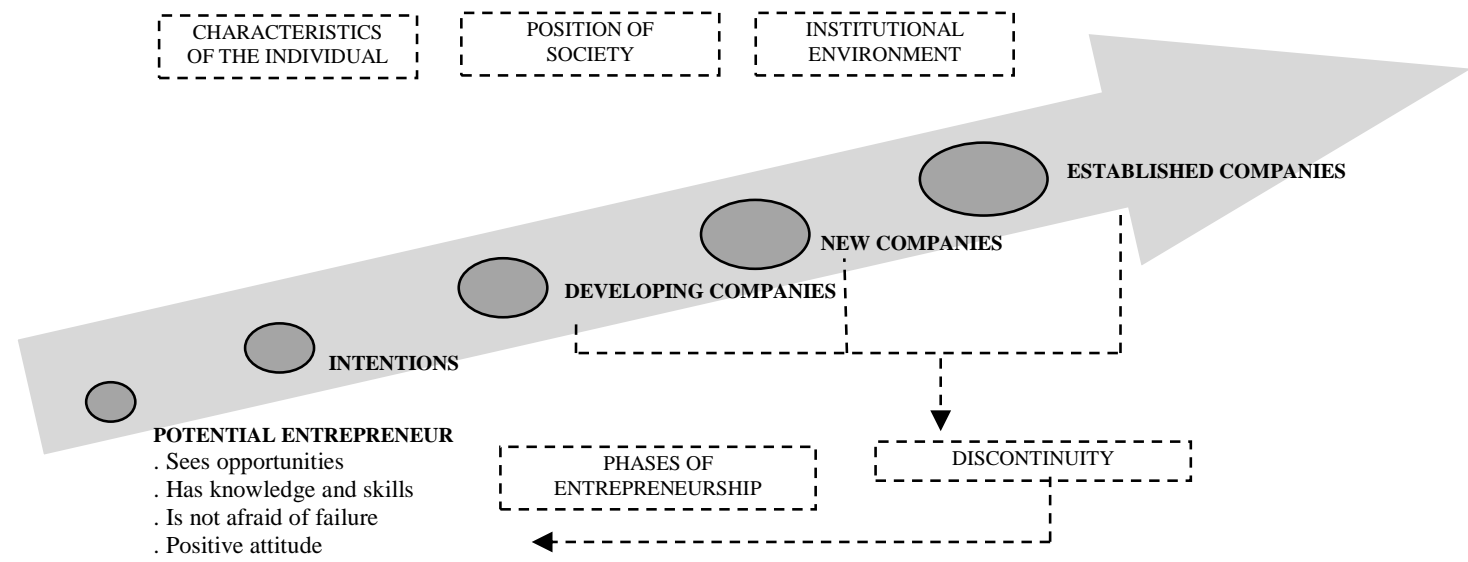

Source: GEM (2019).

In the combination of indicators, countries are classified into three groups: those driven by factors - predominance of activities with heavy dependence on work and natural resources; for efficiency - advancing industrialization and gains in scale, with a predominance of intensive organizations in capital, such as Brazil; and those for innovation - knowledge-intensive enterprises, expansion and modernization of the service sector (table 3). 
Table 3 - Classification of countries participating in GEM 2019 according to their economic characteristics $^{1}-2016$

\begin{tabular}{|c|c|c|c|}
\hline Continent & $\begin{array}{c}\text { Countries driven by } \\
\text { factors (6) }\end{array}$ & $\begin{array}{l}\text { Countries driven by } \\
\text { efficiency (32) }\end{array}$ & $\begin{array}{l}\text { Countries driven by } \\
\text { innovation (27) }\end{array}$ \\
\hline Africa & Burkina Faso. Cameroon & $\begin{array}{l}\text { South Africa, Egypt, } \\
\text { Morocco }\end{array}$ & \\
\hline Asia \& Oceania & Kazakhstan ${ }^{2}$. India. Iran $^{2}$ & $\begin{array}{l}\text { Saudi Arabia }{ }^{3} \text {, China, } \\
\text { Indonesia, Jordan, } \\
\text { Lebanon }^{3}, \text { Malaysia }^{3} \text {, } \\
\text { Thailand Turkey }\end{array}$ & $\begin{array}{l}\text { Australia, Qatar, Korea, } \\
\text { United Arab Emirates, Hong } \\
\text { Kong, Israel, Taiwan }\end{array}$ \\
\hline $\begin{array}{l}\text { Latin America } \\
\text { and Caribbean }\end{array}$ & & $\begin{array}{l}\text { Argentina }^{3}, \text { Brazil, Chile } \\
\text { Colombia, Ecuador, } \\
\text { Guatemala, Mexico } \\
\text { Panama }^{3} \text {, Peru, Uruguay } \\
\text { P }^{3}\end{array}$ & \\
\hline Europe & Russia $^{2}$ & $\begin{array}{l}\text { Bulgaria, Croatia }{ }^{3} \text {, } \\
\text { Slovakia }^{3}, \text { Georgia, } \\
\text { Hungary }^{3}, \text { Latvia }^{3} \text {, } \\
\text { Macedonia, Poland }^{3}\end{array}$ & $\begin{array}{l}\text { Germany, Austria, Cyprus, } \\
\text { Slovenia, Spain, Estonia, } \\
\text { France, Finland Greece, } \\
\text { Netherlands, Ireland Italy, } \\
\text { Luxembourg, Portugal, } \\
\text { United Kingdom, Sweden, } \\
\text { Switzerland }\end{array}$ \\
\hline North America & & Belize, El Salvador, Jamaica & $\begin{array}{l}\text { Canada, The United States, } \\
\text { Puerto Rico }\end{array}$ \\
\hline
\end{tabular}

Notes: ${ }^{1}$ This classification is based on the Global Competitiveness Report - Publication of the World Economic Forum that identifies three phases of economic development, considering Gross Domestic Product (GDP) per capita and the share of exports related to primary goods.

2 Transitioning to efficiency-driven economies.

${ }^{3}$ Transitioning to innovation-driven economies.

Source: GEM (2019)

It is noteworthy that both the REA and the EER had average growth in the last 12 years (2008-2019), standing at 17.6 and 15.8 respectively. This growth shows an entrepreneurial profile of the Brazilian micro and small entrepreneur favorable to business, in which having an enabling environment for the application of the Integrated Sustainability Administration - ISA as a management technology and combined with the dimensions and components of technological capacity, it suggests favoring the success and perennity of MSCs.

The environment of public organizations presents a new Public Management paradigm. Paes-Paula (2005, p. 28) points out two points of view of two lines of thought that guide the constitution of the new public administration model: neoliberal thinking and public choice theory. The ideas of liberal and neoliberal thinking that supported managerialism are related to the "ideal breadth of the role of the State in society and the economy", which among its functions is to provide essential public utility services. Public choice theory argues that economic principles should be applied to explain political issues, such as state theory and bureaucracy. Neoliberal thinking and public choice theory seek an innovative public administration model, with recommendations to bring the management model of public organizations closer to the 
management practices of the private sector, such as the introduction of concepts of performance, efficiency, and responsibility assessment (Hood, 1995).

In this context, Entrepreneurial Public Administration stands out (EPA), in which managerial reform sought to rescue the principles and instruments of business management. It is emphasized that public administrators must guide their conduct not only by the principles of legality, impersonality, morality, publicity, and efficiency of management acts, as established by the 1988 Constitution, but mainly in view of the strict responsibility towards society (Polary, 2019). Another relevant aspect is how to prepare for a career that will give the foundations of a Professional Manager, considering:

The pre-disposition for the career (self-motivation), based on the qualification, personalprofessional awareness, and self-discipline (the degree itself, may or may not be valid); the choice of a prepared university to offer academic training with the quality parameters required by the Ministry of Education and Culture (MEC) and job market; know, understand, master, criticize and apply administrative theory in academia and organizations, reconciling theory with organizational practice.

In Sustainable Public Management, the Integrated Public Management (Polary, 2016) stands out, which is developed considering the academic aspect and the professional performance in Public Administration. In the academic view, one of the reasons for good training is to improve the way organizations are managed. Organizations well administered by managers who apply Integrated Public Management develop consistency, growth, and prosperity, and when mismanaged, they recede and very often, they die. In the "Professional Practice in Public Administration" aspect, we must consider the examples and experiences of good practices that reflect the reality of Brazilian Public Management and other countries.

Thus, Mai et al. (2017) researched on the use of technologies in the democratization of health information at the State Health Secretariat of Rio Grande do Sul (SHS-RS). The Information Technology Management Department (ITMD) aims to present the contribution of the Business Intelligence tool (BI). They point out that the inclusion of technology in work processes has undergone changes, requiring new technological skills, in which operational work is replaced by more analytical one. The possibility of periodic analysis and monitoring of the information generated by the BI Health portal has increased quantitatively and qualitatively the analytical potential of SHS-RS technicians, who have carried out their actions with a focus on planning, monitoring and evaluating health conditions of the population from Rio Grande do Sul state. 
At the State University of Maranhao (UEMA), investments in technology advanced in the 2016-2020 quadrennium, both at the headquarters in São Luis and at the other hubs in the municipalities (UEMA, 2016). It also offers Distance Education (DE) with solid technological structure, and among the investments, two guidelines stand out: adoption and pedagogical and methodological dynamics in teaching, in research and extension projects with a view to the development of technologies and new trends in DE; and offering technological, pedagogical and administrative support for the Onsite Support Poles already in place.

It is understood that the new professional management models applicable to public governance, including that of Integrated Sustainability Administration (ISA), adapted for public organizations (Polary, 2014), as a management technology, combined with the dimensions and components of technological capacity, suggests that it is a viable alternative for the organizational development of public organizations in the provision of services to society.

\section{Method}

The methodology, as described by Lakatos and Marconi (2007), corresponds to the methods of approach, procedure, techniques, the delimitation of the universe, the type of sampling and statistical treatment. Thereby, the methodological path is presented as follows.

In the literature: data extracted from secondary sources. It was based on consistent works with the research lines "Management Technologies" of the Doctorate degree in Administration - Getulio Vargas Foundation (FGV)/Brazilian School of Public and Business Administration (EBAPE); and Administration and Management: study of models of Sustainable Professional Management and Entrepreneurship, Public Administration and MSCs from the Research Group "Administration, Management and State (AMS)" - National Council for Scientific and Technological Development (CNPq) (Polary \& Silva, 2015), Applied Social Sciences area.

Method and theory: Deductive hypothetical method - for the construction of systemic concepts and deduced hypotheses of this explanatory theoretical model (Quivy \& Campenhould, 1995).

Approaches and theories: administration technologies, Public management and entrepreneurship in economic and managerial approaches which supported the ISA (Polary, 2012; 2014).

In the field: in the delimitation of the universe, the 2012 data were from Maranhao industrial MSCs in 170 municipalities that have formal industries (FIEMA, 2006); 2015 
in public hospitals and public universities in Sao Luis-MA; those of 2016 in industrial MSCs and service delivery companies of Sao Luis. Tables 4 to 6 are presented below:

Table 4 - Population for stratification, according to municipal districts for size of the industries

\begin{tabular}{clccc}
\hline \multicolumn{1}{c}{ Municipal districts } & MICRO & SMALL & \multirow{2}{*}{ TOTAL } \\
\hline & & Quantity & Quantity & \\
\hline 01 & Alcantara & 01 & - & 01 \\
02 & Bacabal & 36 & 09 & 45 \\
03 & Balsas & 59 & 21 & 80 \\
04 & Caxias & 17 & 20 & 37 \\
05 & Cajapio & 04 & - & 04 \\
06 & Imperatriz & 192 & 97 & 289 \\
07 & Lago da Pedra & 16 & 03 & 19 \\
08 & Paço do Lumiar & 04 & 01 & 05 \\
09 & Raposa & 02 & - & 02 \\
10 & Rosario & 08 & 08 & 16 \\
11 & Sao Joao dos Patos & 11 & - & 11 \\
12 & Sao Jose de Ribamar & 21 & 09 & 30 \\
13 & São Luis & 739 & 380 & 1119 \\
14 & Timon & 32 & 10 & 42 \\
\hline & Total & 1142 & 558 & 1700 \\
\hline
\end{tabular}

Source: FIEMA (2006).

Table 5 - Universe of the Public Hospitals and Public Universities of São Luis-MA

\begin{tabular}{|c|c|}
\hline Public Hospitals & Public Universities \\
\hline 1. Djalma Marques Socorrao I Hospital & 1. Federal University of Maranhao (UFMA) \\
\hline $\begin{array}{l}\text { 2. Urgency and emergency Dr. Clementino Moura } \\
\text { - Socorrao II Hospital }\end{array}$ & 2. State University of Maranhao (UEMA) \\
\hline 3. Presidente Dutra Universitary Hospital & 3. Federal Institute of Maranhao (IFMA) \\
\hline 4. Aquiles Lisboa Hospital & \\
\hline 5. Locomotor system Sarah Hospital & \\
\hline 6. Tarquinio Lopes Filho General Hospital & \\
\hline 7. Child Hospital Nursery & \\
\hline 8. Nina Rodrigues Hospital & \\
\hline 9. Dr. Juvencio Mattos Child Hospital & \\
\hline 10. Pam Filipinho Hospital & \\
\hline 11. Pam Diamante Hospital & \\
\hline 12. Dr. Adelson Sousa Lopes Hospital & \\
\hline 13. Getulio Vargas Hospital & \\
\hline $\begin{array}{l}\text { 14. Pro-Health Benevolent Association and Social } \\
\text { Ass Hospital }\end{array}$ & \\
\hline 15. Aldenora Belo Hospital & \\
\hline 16. Women Hospital & \\
\hline 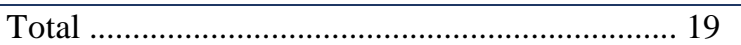 & \\
\hline
\end{tabular}

Source: Altillo (2020) and Secretaria Municipal de Saúde - Municipal Health Secretariat [SEMUS] (2021) with updated information by the author. 
Table 6 - MCs and SCs population active for stratification in Sao Luis-MA by size

\begin{tabular}{|c|c|c|c|c|}
\hline \multirow{3}{*}{$\mathbf{N}^{\circ}$} & \multirow{3}{*}{ Municipal district } & \multicolumn{2}{|c|}{ Size of the companies } & \multirow{3}{*}{ Total } \\
\hline & & $\begin{array}{l}\text { Micro Company } \\
\text { (MC) }\end{array}$ & Small Company (SC) & \\
\hline & & Quantity & Quantity & \\
\hline 01 & & 14.183 & 929 & 15.112 \\
\hline
\end{tabular}

Source: Junta Comercial do Maranhão [JUCEMA] (2016).

From the universe of MSCs in 2012, a proportional stratified random sample was extracted, considering the participation of each economic category in Maranhao GDP, as shown in table 7 and 8.

Table 7 - Significant stratified industry samples according to municipalities by size

\begin{tabular}{llccc}
\hline \multirow{2}{*}{$\mathbf{N}^{\mathbf{0}}$} & Municipal Districts & Micro & Small & \multirow{2}{*}{ Total } \\
\cline { 3 - 4 } & & Quantity & Quantity & \\
\hline 01 & Alcantara & 01 & - & 01 \\
02 & Bacabal & 03 & 02 & 05 \\
03 & Balsas & 06 & 02 & 08 \\
04 & Caxias & 02 & 02 & 04 \\
05 & Cajapio & 01 & - & 01 \\
06 & Imperatriz & 16 & 08 & 24 \\
07 & Lago da Pedra & 03 & 02 & 05 \\
08 & Paço do Lumiar & 02 & 01 & 03 \\
09 & Raposa & 01 & - & 01 \\
10 & Rosario & 02 & 01 & 03 \\
11 & Sao Joao dos Patos & 01 & - & 01 \\
12 & Sao Jose de Ribamar & 02 & 01 & 03 \\
13 & Sao Luis & 51 & 22 & 73 \\
14 & Timon & 02 & - & 02 \\
\hline & Total & 93 & 41 & 134 \\
\hline
\end{tabular}

Source: FIEMA (2006).

Table 8 - GDP 14 municipalities in the sample of 134 MSCs in Industrial Sector -MA

\begin{tabular}{|c|c|c|c|}
\hline $\mathbf{N}^{\mathbf{0}}$ & Municipal District & GDP at current price & $\%$ \\
\hline 1 & Alcantara & $\mathrm{R} \$ 65.418 .000,00$ & $0,17 \%$ \\
\hline 2 & Bacabal & $\mathrm{R} \$ 505.600 .000,00$ & $1,27 \%$ \\
\hline 3 & Balsas & $\mathrm{R} \$ 1.120 .221 .000,00$ & $2,82 \%$ \\
\hline 4 & Cajapio & $\mathrm{R} \$ 22.781 .000,00$ & $0,06 \%$ \\
\hline 5 & Caxias & $\mathrm{R} \$ 825.527 .000,00$ & $2,08 \%$ \\
\hline 6 & Imperatriz & $\mathrm{R} \$ 2.000 .735 .000,00$ & $5,03 \%$ \\
\hline 7 & Lago da Pedra & $\mathrm{R} \$ 152.435 .000,00$ & $0,38 \%$ \\
\hline 8 & Paço do Lumiar & $\mathrm{R} \$ 291.564 .000,00$ & $0,73 \%$ \\
\hline 9 & Raposa & $\mathrm{R} \$ 100.920 .000,00$ & $0,25 \%$ \\
\hline 10 & Rosario & $\mathrm{R} \$ 134.819 .000,00$ & $0,34 \%$ \\
\hline 11 & Sao Joao dos Patos & $\mathrm{R} \$ 89.164 .000,00$ & $0,22 \%$ \\
\hline 12 & Sao Jose de Ribamar & $\mathrm{R} \$ 473.407 .000,00$ & $1,19 \%$ \\
\hline 13 & Sao Luis & $\mathrm{R} \$ 15.337 .347 .000,00$ & $38,58 \%$ \\
\hline \multirow[t]{4}{*}{14} & Timon & $\mathrm{R} \$ 715.427 .000,00$ & $1,81 \%$ \\
\hline & TOTAL GDP (municipalities participating in the survey) & $\mathrm{R} \$ 21.835 .365 .000,00$ & $54,93 \%$ \\
\hline & $\begin{array}{l}\text { TOTAL GDP (municipalities not participating in the } \\
\text { research) }\end{array}$ & $\mathrm{R} \$ 17.918 .346 .000,00$ & $45,07 \%$ \\
\hline & GDP Maranhao & $\mathrm{R} \$ 39.753 .711 .000,00$ & $100 \%$ \\
\hline
\end{tabular}

Source: Gross Domestic Product of Maranhao municipalities - 2009 (Brazilian Institute of Geography and Statistics [IBGE], 2012). 
From the universe of public organizations in 2015, a simple random sample was extracted, and in MCs and SCs in 2016, a sample for accessibility (tables 9 and 10).

Table 9 - Sample selected by means of simple random sampling

\begin{tabular}{|l|l|}
\hline \multicolumn{1}{|c|}{ Public Hospitals } & Higher Education Institutions (HEIs) \\
\hline 1. Djalma Marques - Socorrao I Hospital & 6. State University of Maranhao - UEMA \\
\hline $\begin{array}{l}\text { 2. Urgency and emergency Dr. Clementino Moura - Socorrao } \\
\text { II Hospital }\end{array}$ & $\begin{array}{l}\text { 7. Federal University of Maranhao - } \\
\text { UFMA }\end{array}$ \\
\hline 3. Women Hospital & \\
\hline 4. Children's Hospital & \\
\hline 5. Pam Diamante Center for Medical Specialties and Diagnosis & \\
\hline
\end{tabular}

Source: Altillo (2020) and SEMUS (2021) with updated information by the author.

Table 10 - Accessibility sample active MCs and SCs for stratification in Sao Luis-MA

\begin{tabular}{lcccc}
\hline \multirow{2}{*}{$\mathbf{N}^{\mathbf{0}}$} & Municipal district & \multicolumn{3}{c}{ Size of the companies } \\
\cline { 3 - 5 } & & $\begin{array}{c}\text { MC } \\
\text { Quantity }\end{array}$ & $\begin{array}{c}\text { SC } \\
\text { Quantity }\end{array}$ & Total \\
\hline 01 & Sao Luis & 22 & 16 & 38 \\
\hline
\end{tabular}

Source: JUCEMA (2016).

Data collection: the data collection technique was the questionnaire, applied to the partners and other managers who managed the MCs and SCs (also called Small load Companies - SLCs), industrial and service delivery ones, and to managers and employees in public organizations of the samples. Among the collected data, the following stand out:

The 12 variables of the ISA that most positively influenced the management, success and perennity of industrial MSCs in 2012, and favorably in the organizational excellence of public organizations in 2015, on a scale from 1 to 10 , in importance degree; the most important variables of the ISA model for the success of MSCs in 2012 and 2016 in the phases of creation, maintenance, perennial maintenance, growth and perpetuity, on a scale from 1 to 10; technology variables of the ISA model that most contribute to the perennity of MCs and SCs in 2016; the major contributions of public organizations in the sample in fulfilling their institutional mission with their external customers, server satisfaction, relevance to society and organizational excellence of services. The measurement scales of Malhotra (2006), and Ulrich et al. (2009), served as the basis for scoring variables on the scale from 1 to 10 of the research questionnaires.

Data analysis: the data collected in the MSCs of the industrial sample (Polary, 2012), received statistical treatment: descriptive analysis, Levene homogeneity test of variances and analysis of variance (ANOVA), correlation test, regression and multiple 
correlation; with the collected data at public hospitals and public universities in Sao Luis-MA (Polary \& Silva, 2015) descriptive analysis was performed: average, minimum, maximum and standard deviation (SD); and data collected from MCs and SCs from the industrial and service sectors in Sao Luis (Polary et al., 2016), weighted arithmetic average calculation was adopted. These analyzes were carried out in the light of the research objectives, the problem investigated and the hypothesis raised to achieve the obtained results.

\section{Results and discussion}

In the analysis of the results of the research on the application of ISA (Polary, 2012) in MCs, it was found that the Technological Administrative, Social Economic and Institutional Political dimensions (table 1), were those that presented the highest averages, respectively $(8,9$, 8,0 and 6,3), followed by management and technology components; economic and social indicators; policies and strategies; and their respective variables. By analyzing the 12 variables of the ISA model, among the predominant 06, the variable "Managerial skills and abilities of the partners who manage - Professional Administration - ISA, based on Entrepreneurship", was the one that most positively influenced Management, Success and Perennity in the MCs sample, with an average of 8.99 (table 11).

Table 11 - The 06 variables of the ISA model that most positively influence the Management, Success and Perennity of the industrial MCs in Maranhao, in the view of managers

\begin{tabular}{|c|c|c|c|c|c|c|}
\hline Variables & $\mathbf{n}$ & $\%$ & Average & Minimum & Maximum & $\begin{array}{l}\text { Standard } \\
\text { deviation }\end{array}$ \\
\hline $\begin{array}{l}\text { 1. Management skills and abilities of the } \\
\text { partners who manager and those who } \\
\text { administer or advise the business - } \\
\text { Professional Administration-ISA, based on }\end{array}$ & & & & & & \\
\hline Entrepreneurship.............. & 92 & 98.92 & 8.99 & 1 & 10 & 1.5442 \\
\hline $\begin{array}{l}\text { 2. Technological support (machinery and } \\
\text { equipment; systems and working methods) }\end{array}$ & 90 & 96.77 & 8.86 & 1 & 10 & 1.5107 \\
\hline 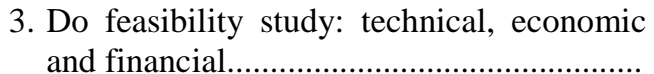 & 88 & 94.62 & 8.83 & 3 & 10 & 1.5773 \\
\hline 4. Skilled industrial labor................................. & 92 & 98.92 & 8.63 & 1 & 10 & 2.1315 \\
\hline 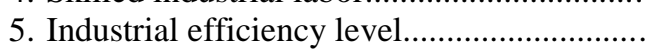 & 92 & 98.92 & 8.62 & 4 & 10 & 1.4207 \\
\hline 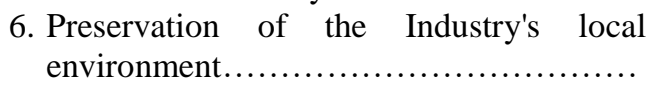 & 90 & 96.77 & 8.58 & 1 & 10 & 2.1093 \\
\hline
\end{tabular}

Source: Polary (2012).

When the 06 most important variables for the success of MCs were verified in perennity phase, among the 12 of the ISA model, the results were as shown in table 12 . 
Table 12 - The 06 most important variables for the success of Maranhao's industrial MCs in perennity phase

\begin{tabular}{|c|c|c|c|c|c|c|}
\hline Variables & n & $\%$ & Average & Minimum & Maximum & $\begin{array}{l}\text { Standard } \\
\text { deviation }\end{array}$ \\
\hline $\begin{array}{l}\text { 1. Reinvest in Micro Companies to better serve its } \\
\text { workforce, customers and fulfill its economic and } \\
\text { social function to remain successfully in the } \\
\text { market, in the view of managers..................................... }\end{array}$ & 90 & 96.77 & 9.38 & 6 & 10 & 0.9189 \\
\hline 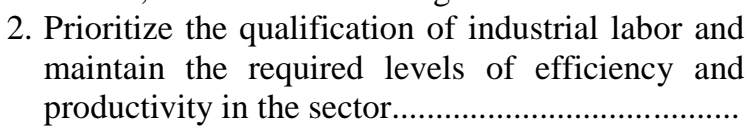 & 93 & 100.00 & 9.25 & 1 & 10 & 1.4192 \\
\hline $\begin{array}{l}\text { 3. Prioritize the technical and professional } \\
\text { development of the partners who manage and those } \\
\text { who administer or advise the company........ }\end{array}$ & 93 & 100.00 & 9.22 & 3 & 10 & 1.3092 \\
\hline 4. Preservation of the industry's local environment... & 92 & 98.92 & 8.88 & 3 & 10 & 1.5956 \\
\hline $\begin{array}{l}\text { 5. Use the Industrial Development Plan - PDI } 2020 . . \\
\text { 6. Public policies of the Federal, State and Municipal }\end{array}$ & 84 & 90.32 & 7.24 & 1 & 10 & 2.8523 \\
\hline $\begin{array}{l}\text { Governments, investment attractions and MCs } \\
\text { partnerships with the Government and private } \\
\text { sectors }\end{array}$ & 91 & 97.85 & 6.77 & 1 & 10 & 3.0553 \\
\hline
\end{tabular}

Source: Polary (2012).

In SCs, it was found that the Technological Administrative, Social Economic and Institutional Political dimensions of the ISA model, were the ones with the highest averages, respectively $(8,7,8,1$ and 7,3), followed by management and technology components; economic and social indicators; and policies and strategies; and its variables. By analyzing the 12 variables of the ISA model, among the 6 predominant ones, it was found that the variable, "Managerial competencies and skills of the members who manage - Professional Management - ISA, based on Entrepreneurship", was the one that most positively influenced Management, Success and Perennity in SCs, with an average of 8.95 (table 13).

Table 13 - The 06 variables of the ISA model that most positively influence the Management, Success and Perennity of Maranhao's industrial SCs

\begin{tabular}{|c|c|c|c|c|c|c|}
\hline Variables & $\mathbf{n}$ & $\%$ & Average & Minimum & Maximum & $\begin{array}{l}\text { Standard } \\
\text { deviation }\end{array}$ \\
\hline $\begin{array}{l}\text { 1. Management skills and abilities of the partners } \\
\text { who manager and those who administer or advise } \\
\text { the business - Professional Administration (ISA), } \\
\text { based } \\
\text { Entrepreneurship............................................ }\end{array}$ & 41 & 100.00 & 8.95 & 7 & 10 & 1.0476 \\
\hline $\begin{array}{l}\text { 2. Technological support (machinery } \\
\text { equipment; systems and working methods) }\end{array}$ & 41 & 100.00 & 8.80 & 7 & 10 & 0.9992 \\
\hline 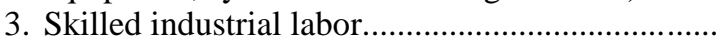 & 41 & 100.00 & 8.61 & 5 & 10 & 1.4980 \\
\hline 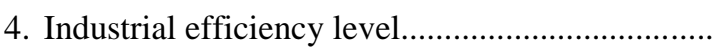 & 40 & 97.56 & 8.58 & 6 & 10 & 1.1068 \\
\hline 5. Small Companies Location........................................ & 41 & 100.00 & 8.56 & 4 & 10 & 1.4841 \\
\hline 6. Preservation of the industry's local environment. & 41 & 100.00 & 8.44 & 1 & 19 & 2.7023 \\
\hline
\end{tabular}

Source: Polary (2012). 
When checking which 06 variables are most important for the success of SCs in perennity phase, among the 12 of the ISA model, the results were as shown in the table 14 .

Table 14 - The 06 most important variables for the success of Maranhao's industrial SCs in perennity phase

\begin{tabular}{|c|c|c|c|c|c|c|}
\hline Variables & $\mathbf{n}$ & $\%$ & Average & Minimum & Maximum & $\begin{array}{l}\text { Standard } \\
\text { deviation }\end{array}$ \\
\hline 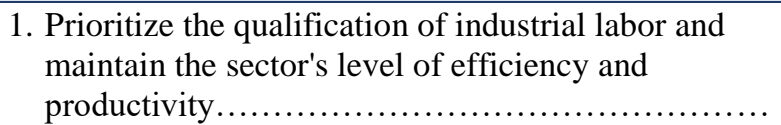 & 41 & 100.00 & 9.20 & 5 & 10 & 1.1878 \\
\hline 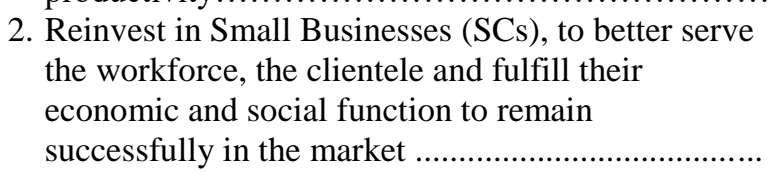 & 41 & 100.00 & 9.10 & 4 & 10 & 1.2001 \\
\hline $\begin{array}{l}\text { 3. Prioritize the technical and professional } \\
\text { development of the partners who manage and those } \\
\text { who administer or advise the business to the SCs.... }\end{array}$ & 41 & 100.00 & 9.07 & 6 & 10 & 1.2528 \\
\hline 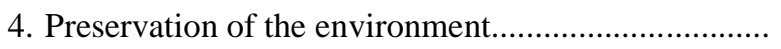 & 41 & 100.00 & 8.56 & 4 & 10 & 1.5008 \\
\hline $\begin{array}{l}\text { 5. Use the Industrial Development Plan - PDI } 2020 \ldots . \\
\text { 6. Public Policies of the Federal, State and Municipal }\end{array}$ & 40 & 97.56 & 8.20 & 4 & 10 & 1.7127 \\
\hline $\begin{array}{l}\text { Governments, investment attractions and } \\
\text { partnership with the SCs, the Government and } \\
\text { private sector........................................... }\end{array}$ & 41 & 100.00 & 7.51 & 2 & 10 & 2.0140 \\
\hline
\end{tabular}

Source: Polary (2012).

By the results of the Levene's Test of Homogeneity of ANOVA of the variables of the ISA, applied in industrial micro, small, medium and large companies (MSMLCs) of the sample, it was verified in the view of the managers (partners and other managers), that of the 12 variables of the ISA model (table 1), the conclusions point out that only in the variable "Local Strategies and Institutional Political Partnerships, Industrial Segment and Civil Society" there are differences among the averages, as described in tables 15 and 16.

Table 15 - Levene Test of Homogeneity of Variances: Local Strategies and Institutional Political Partnerships, Industrial Segment and Civil Society, which positively influence the Management, Success and Perennity of industrial MSMLCs of Maranhao

\begin{tabular}{|c|c|c|c|c|c|c|c|c|}
\hline \multirow{2}{*}{$\begin{array}{c}\text { Study } \\
\text { variable }\end{array}$} & \multicolumn{3}{|c|}{ Among groups } & \multicolumn{3}{|c|}{ Within groups } & \multirow[b]{2}{*}{$\mathbf{F}$} & \multirow[b]{2}{*}{$\mathbf{P}$} \\
\hline & $\begin{array}{l}\text { Sum of } \\
\text { Squares }\end{array}$ & GL & $\begin{array}{l}\text { Medium } \\
\text { Square }\end{array}$ & $\begin{array}{l}\text { Sum of } \\
\text { Squares }\end{array}$ & GL & $\begin{array}{l}\text { Medium } \\
\text { Square }\end{array}$ & & \\
\hline $\begin{array}{l}\text { Local Strategies and } \\
\text { Institutional Political } \\
\text { Partnerships and Civil } \\
\text { Society, which } \\
\text { positively influence } \\
\text { the Management, } \\
\text { Success and Perennity } \\
\text { of MSMLCs. }\end{array}$ & 9.089635 & 2 & 4.544817 & 313.1082 & 133 & 2.354197 & 1.930517 & 0.149117 \\
\hline
\end{tabular}

Source: Polary (2012). 
Table 16 - Variance Analysis: Local strategies and institutional political partnerships, industrial segment and civil society, which positively influence the Management, Success and Perennity of industrial MSMLCs of Maranhao.

\begin{tabular}{|c|c|c|c|c|c|c|c|c|}
\hline \multirow{2}{*}{$\begin{array}{c}\text { Study } \\
\text { variable }\end{array}$} & \multicolumn{3}{|c|}{ Among groups } & \multicolumn{3}{|c|}{ Within groups } & \multirow[b]{2}{*}{$\mathbf{F}$} & \multirow[b]{2}{*}{$\mathbf{P}$} \\
\hline & $\begin{array}{c}\text { Sum of } \\
\text { Squares }\end{array}$ & GL & $\begin{array}{l}\text { Medium } \\
\text { Square }\end{array}$ & $\begin{array}{l}\text { Sum of } \\
\text { Squares }\end{array}$ & GL & $\begin{array}{l}\text { Medium } \\
\text { Square }\end{array}$ & & \\
\hline $\begin{array}{l}\text { Local Strategies and } \\
\text { Institutional Political } \\
\text { Partnerships and Civil } \\
\text { Society, which } \\
\text { positively influence } \\
\text { the Management, } \\
\text { Success and Perennity } \\
\text { of MSMLCs }\end{array}$ & 71.74439 & 2 & 35.87219 & 1132.491 & 133 & 8.514969 & 4.212839 & 0.016827 \\
\hline
\end{tabular}

Source: Polary (2012)

Considering the structure for the ANOVA, the statistical results contained in the Tables and the value of $\mathrm{F} \alpha ; v_{1} ; ; v_{2}$; critical extracted from the Distribution Table F with $v_{1}=2$ and $v_{2}=$ 133, are respectively, the degrees of freedom of the numerator (among groups) and of the denominator (within groups), thus:

H0: The averages are equal. H1: There is a difference among the averages

$\alpha=0.05$ (significance level of the test). $F=4.212839$. F $v 1 ; ; v 2=3.07$

Conclusion: If $\mathrm{F}$ calculated $\geq \mathrm{F}$ critical $=>\mathrm{H}_{0}$ is rejected; otherwise, $\mathrm{H}_{0}$ is accepted.

As the sentence $4.212839 \geq 3.07$ is True, so There is a difference among the averages.

As the Levene Test of Homogeneity of Variances and Analysis of Variance demonstrated that there is no difference among the averages of the other 11 variables in the Model (table 1), they are presented as an example, the conclusions of the variable “Technological Support (machinery and equipment, systems and working methods), that point out that there is no difference among the averages, as described in table 17 and 18.

Table 17 - Levene Test of Homogeneity of Variances: Technological support that most positively influences the Management, Success and Perennity of industrial MSMLCs - MA

\begin{tabular}{|c|c|c|c|c|c|c|c|c|}
\hline \multirow{2}{*}{$\begin{array}{c}\text { Study } \\
\text { Variable }\end{array}$} & \multicolumn{3}{|c|}{ Among Groups } & \multicolumn{3}{|c|}{ Within Groups } & \multirow[b]{2}{*}{$\mathbf{F}$} & \multirow[b]{2}{*}{$\mathbf{p}$} \\
\hline & $\begin{array}{c}\text { Sum of } \\
\text { Squares }\end{array}$ & GL & $\begin{array}{l}\text { Medium } \\
\text { Square }\end{array}$ & $\begin{array}{c}\text { Sum of } \\
\text { Squares }\end{array}$ & GL & $\begin{array}{l}\text { Medium } \\
\text { Square }\end{array}$ & & \\
\hline $\begin{array}{l}\text { Technological Support } \\
\text { (machinery and } \\
\text { equipment, systems and } \\
\text { working methods), which } \\
\text { most positively influence } \\
\text { the Management, Success } \\
\text { and Perennity of } \\
\text { MSMLCs. }\end{array}$ & 2.262827 & 2 & 1.131413 & 173.7208 & 139 & 1.249790 & 0.905283 & 0.406798 \\
\hline
\end{tabular}

Source: Polary (2012). 
Table 18 - Analysis of Variance: Technological support that most positively influences the Management, Success and Perennity of industrial MSMLCs of Maranhao.

\begin{tabular}{|c|c|c|c|c|c|c|c|c|}
\hline \multirow{2}{*}{$\begin{array}{c}\text { Study } \\
\text { Variable }\end{array}$} & \multicolumn{3}{|c|}{ Among Groups } & \multicolumn{3}{|c|}{ Within Groups } & \multirow[b]{2}{*}{$\mathbf{F}$} & \multirow[b]{2}{*}{ p } \\
\hline & $\begin{array}{c}\text { Sum of } \\
\text { Squares }\end{array}$ & GL & $\begin{array}{l}\text { Medium } \\
\text { Square }\end{array}$ & $\begin{array}{c}\text { Sum of } \\
\text { Squares }\end{array}$ & GL & $\begin{array}{c}\text { Medium } \\
\text { Square }\end{array}$ & & \\
\hline $\begin{array}{l}\text { Technological Support } \\
\text { (machinery and } \\
\text { equipment, systems } \\
\text { and working } \\
\text { methods), which most } \\
\text { positively influence } \\
\text { the Management, } \\
\text { Success and Perennity } \\
\text { of MSMLCs. }\end{array}$ & 0.362827 & 2 & 0.181413 & 409.4963 & 139 & 2.946017 & 0.061579 & 0.940304 \\
\hline
\end{tabular}

Considering the structure for the ANOVA, the statistical results contained in the Tables and the value of $\mathrm{F} \alpha ; v_{1 ;} ; v_{2}$; critical extracted from the Distribution Table $\mathrm{F}$ with $v_{1}=2$ and $v_{2}=$ 139 , are, respectively, the degrees of freedom of the numerator (among groups) and of the denominator (within groups), we have:

H0: The averages are equal. H1: There is difference among the averages

$\alpha=0.05$ (significance level of the test). $\mathrm{F}=0.061579$. $\mathrm{F} v 1 ; ; v 2=3.07$. Conclusion: If $\mathrm{F}$ calculated $\geq \mathrm{F}$ critical $=>\mathrm{H}_{0}$ is rejected; otherwise, $\mathrm{H}_{0}$ is accepted.

As the sentence $0.061579 \geq 3.07$ is False, so There is not a difference among the averages.

The tests were performed using the level of significance of $5 \%$, thus with $95 \%$ of probability of getting the test validity right.

Correlation test: by the correlation test among "the variables that most positively influence and that most negatively interfere in the Management, Success and Perennity of Industrial MCs of the sample", of the Integrated Sustainability Administration - ISA, substantial positive correlation prevailed among the variables "do feasibility study and lack of feasibility study" and "qualified industrial labor and disqualified industrial labor", in the view of managers, according to tables 19 and 20. 
Table 19 - Correlation test among variables Do feasibility studies: technical, economic and financial that positively influence and Lack of feasibility studies: technical, economic and financial that negatively interfere in MCs, in the view of managers

\begin{tabular}{|c|c|c|}
\hline Variables & $\begin{array}{c}\text { Pearson's } \\
\text { correlation }\end{array}$ & $\begin{array}{l}\text { Significance } \\
\text { of the test (p) }\end{array}$ \\
\hline $\begin{array}{l}\text { Conduct feasibility studies: technical, economic and financial } \\
\text { and } \\
\text { Lack of feasibility studies: technical, economic and financial }\end{array}$ & 0,54352 & $\mathrm{p}=0,00$ \\
\hline
\end{tabular}
Source: Polary (2012)

The correlation is significant for $\mathrm{p}<0,0500$. Conclusion: Substantial positive correlation.

Table 20 - Correlation test among the variables Qualified industrial labor that positively influences and Disqualified industrial labor that negatively interferes in the MCs, in the view of managers

\begin{tabular}{ccc}
\hline Variables & $\begin{array}{c}\text { Pearson's } \\
\text { correlation }\end{array}$ & $\begin{array}{c}\text { Significance } \\
\text { of the test (p) }\end{array}$ \\
\hline $\begin{array}{c}\text { Qualified industrial labor } \\
\text { and }\end{array}$ & 0,5296 & $\mathrm{p}=0,00$ \\
Disqualified industrial labor & & \\
\hline
\end{tabular}

Source: Polary (2012)

The correlation is significant for $\mathrm{p}<0,0500$. Conclusion: Substantial positive correlation.

By the correlation test among "the variables that most positively influence and that most negatively interfere in the Management, Success and Perennity of Small Companies - Industrial SCs of the sample", substantial positive correlation prevailed among the variables "qualified industrial labor and disqualified industrial labor", in the view of managers, as shown in table 21, and among the three that presented a moderate positive correlation is "technological contribution that positively influences and technological contribution that interferes negatively", as shown in table 22.

Table 21 - Correlation test among the variables Qualified industrial labor that positively influences and Disqualified industrial labor that negatively interferes in SCs, in the view of managers

\begin{tabular}{ccc}
\hline Variables & $\begin{array}{c}\text { Pearson's } \\
\text { correlation }\end{array}$ & $\begin{array}{c}\text { Significance } \\
\text { of the test (p) }\end{array}$ \\
\hline $\begin{array}{c}\text { Qualified industrial labor } \\
\text { and } \\
\text { Disqualified industrial labor }\end{array}$ & 0,5234 & $\mathrm{p}=0,000$ \\
\hline Source: Polary $(2012))$ & &
\end{tabular}

Source: Polary (2012) 
The correlation is significant for $p<0,0500$ Conclusion: Substantial positive correlation.

Table 22 - Correlation test among the Technological Support variable (machinery and equipment; systems and working methods) which positively influences and which negatively interferes in SCs, in the view of managers

\begin{tabular}{ccc}
\hline \multicolumn{1}{c}{ Variables } & $\begin{array}{c}\text { Pearson's } \\
\text { correlation }\end{array}$ & $\begin{array}{c}\text { Significance } \\
\text { of the test (p) }\end{array}$ \\
\hline $\begin{array}{c}\text { Technological support (machinery and equipment, systems and working } \\
\text { methods) that positively influences } \\
\text { and }\end{array}$ & $0,31966 \quad \mathrm{p}=0,047$ \\
$\begin{array}{l}\text { Technological support (machinery and equipment, systems and working } \\
\text { methods) that negatively interferes }\end{array}$ & & \\
\hline Source: Polary (2012) &
\end{tabular}

The correlation is significant for $\mathrm{p}<0,0500$. Conclusion: Moderate positive correlation.

Regression and Multiple Correlation: by the results of the Regression and Multiple Correlation of the 06 variables that most positively influence the Management, Success and Perennity of MCs (Independent - table 11) and the 06 most important ones for the success of MCs in perennity phase (Dependent - table 12) of the Integrated Sustainability Administration - ISA, it was found that the variable "Do feasibility studies: technical, economic and financial" presented the multiple correlation coefficients $(\mathrm{Rxy})=0.6791$ and 0.6712 (substantial positive correlation), and in the coefficients of determination, it means that $46.12 \%$ and $45,05 \%$ of $\mathrm{Y}$ variation can be explained by the model, so it was the variable that had the lowest $\mathrm{p}$ value (table 26), therefore it is the one that most explains the Y variation (Dependent), followed by the variable "Technological support (machinery and equipment, systems and working methods)", with multiple correlation coefficients $(\mathrm{Rxy})=0.6140$ and 0.5369 (Substantial positive correlation) and in the coefficients of determination, it means that $37.70 \%$ and $23.87 \%$ of Y variation (Dependent) can be explained by the model, with a lower p-value (table 23), according to table 23 and 24. 
Table 23 - Multiple linear regression among the variables that most positively influence Management, Success and Permanence (Independent) and Prioritize the qualification of industrial labor and maintain the required levels of efficiency and productivity in the sector (Dependent) in industrial MCs of Maranhao, in the view of managers

\begin{tabular}{|c|c|c|c|}
\hline $\begin{array}{l}\text { Independent } \\
\text { variables } \\
\text { (Peditoras) }\end{array}$ & $\begin{array}{l}\text { Partial } \\
\text { regression } \\
\text { coefficient }\end{array}$ & $\mathbf{t}$ & $\mathbf{P}$ \\
\hline Constant (Intercept) & 1.4039 (a) & - & - \\
\hline $\begin{array}{l}\text { Management skills and abilities of the partners who manage and those who } \\
\text { administer or advise the business - Professional Management (ISA), based } \\
\text { on Entrepreneurship. }\end{array}$ & $0.0234(\mathrm{~b} 1)$ & 0.2571 & 0.7977 \\
\hline $\begin{array}{l}\text { Technological support (machinery and equipment; systems and working } \\
\text { methods) }\end{array}$ & $0.2817(\mathrm{~b} 2)$ & 2.9741 & 0.0038 \\
\hline To do feasibility studies: technical, economic and financial & $0.3615(b 3)$ & 3.6469 & 0.0004 \\
\hline Qualified industrial labor & $-0.0444(\mathrm{~b} 4)$ & -0.7225 & 0.4719 \\
\hline Industrial efficiency level & $0.2301(\mathrm{~b} 5)$ & 2.3558 & 0.0207 \\
\hline Preservation of the industry's local environment & $0.0414(\mathrm{~b} 6)$ & 0.5946 & 0.5536 \\
\hline
\end{tabular}

By the regression equation, $\mathrm{p}<0.0001$. Multiple determination coefficient $(\mathrm{R} 2 \mathrm{xy})=$ 0.4612. Multiple correlation coefficient $(\mathrm{Rxy})=0.6791$ (Substantial positive correlation)

Conclusion: $\mathrm{F}$ is significant for $\mathrm{p}<0.0001$, at least one of the Independent variables (Peditoras) influences on the Dependent variable; The coefficient of determination means that $46.12 \%$ of $\mathrm{Y}$ variation can be explained by the model, the remaining ones $(53.88 \%)$ are inexplicable and due to other factors or to chance; The variable that has the lowest $p$ value is "Do feasibility studies: technical, economic and financial", therefore it is the one that most explains the $\mathrm{Y}$ variation.

Table 24 - Multiple linear regression among the variables that most positively influence Management, Success and Perennity (Independent) and Prioritize the technical and professional development of the partners who manage and others who administer or advise the business (Dependent) at industrial MCs of Maranhao, in the view of managers

\begin{tabular}{lccc}
\hline \multicolumn{1}{c}{$\begin{array}{c}\text { Independent } \\
\text { variables } \\
\text { (Peditoras) }\end{array}$} & $\begin{array}{c}\text { Partial } \\
\text { regression } \\
\text { coefficient }\end{array}$ & t & P \\
\hline $\begin{array}{l}\text { Constant (Intercept) } \\
\text { Management skills and abilities of the partners who manage and those who }\end{array}$ & $2.7637(\mathrm{a})$ & - & - \\
$\begin{array}{l}\text { administer or advise the business - Professional Management (ISA), based } \\
\text { on Entrepreneurship }\end{array}$ & $0.0531(\mathrm{~b} 1)$ & 0.5888 & 0.5575 \\
Technological support (machinery and equipment; systems and working & & & \\
methods) & $\mathbf{0 . 2 8 8 8 ( b 2 )}$ & $\mathbf{3 . 0 7 4 5}$ & $\mathbf{0 . 0 0 2 8}$ \\
To do feasibility studies: technical, economic and financial & $0.2944(\mathrm{~b} 3)$ & 2.9941 & 0.0036 \\
Qualified industrial labor & $-0.0446(\mathrm{~b} 4)$ & -0.7317 & 0.4663 \\
Industrial efficiency level & $0.1292(\mathrm{~b} 5)$ & 1.3332 & 0.1859 \\
Preservation of the industry's local environment & $0.0116(\mathrm{~b} 6)$ & 0.1676 & 0.8676 \\
\hline
\end{tabular}

Source: Polary (2012). 
By the regression equation, $\mathrm{p}<0.0001$. Multiple determination coefficient $(\mathrm{R} 2 \mathrm{xy})=$ 0.3770 . Multiple correlation coefficient $(\mathrm{Rxy})=0.6140$ (Substantial positive correlation)

Conclusion: $\mathrm{F}$ is significant for $\mathrm{p}<0.0001$, at least one of the Independent variables (Peditoras) influences the Dependent variable; the coefficient of determination means that $37.70 \%$ of Y variation can be explained by the model, the remaining ones (62.30\%) inexplicable and due to other factors or to chance; the variable that has the lowest $\mathrm{p}$ value is the variable "Technological support (machinery and equipment; systems and working methods)", therefore it is the one that most explains the $\mathrm{Y}$ variation.

In SCs, it was verified by the results of the Regression and Multiple Correlation of the 06 variables that most positively influence in Management, Success and Perennity (Independent - table 13) and the 06 most important for success in perennity phase (Dependent - table 14)", of the Integrated Sustainability Administration - ISA, that the variable "Qualified industrial labor", presented multiple correlation $(\mathrm{Rxy})=0.6460$ (substantial positive correlation), and in the coefficients of determination means that 41,73 , of $\mathrm{Y}$ variation can be explained by the model, the remaining ones (58.27\%) inexplicable and due to other factors or chance, so it was the variable that had the lowest $\mathrm{p}$ value (table 25), therefore it is the one that most explains the variation and Y (Dependent), followed by: "business location" and "Technological Support" (machinery and equipment, systems and working methods), who presented multiple correlation coefficients $(\mathrm{Rxy})=0.6333$ and 0.5562 (Substantial positive correlation) and in the coefficient of determination, it means that $40,11 \%$ e $30,93 \%$ of Y variation (Dependent) can be explained by the model.

Table 25 - Multiple linear regression among the variables that most positively influence Management, Success and Perennity (Independent) and Reinvest in SCs to better serve their workforce, clientele and fulfill their economic and social function in order to remain successful in the market (Dependent) in industrial SCs-MA, in the view of managers

\begin{tabular}{|c|c|c|c|}
\hline $\begin{array}{l}\text { Independent } \\
\text { variables } \\
\text { (Peditoras) }\end{array}$ & $\begin{array}{l}\text { Partial } \\
\text { regression } \\
\text { coefficient }\end{array}$ & $\mathbf{t}$ & $\mathbf{P}$ \\
\hline Constant (Intercept) & 1.9189 (a) & - & - \\
\hline $\begin{array}{l}\text { Managerial skills and abilities of the partners who manage and those who } \\
\text { administer or advise the business combined with Professional Management } \\
\text { (ISA) and Entrepreneurship. }\end{array}$ & $0.2420(\mathrm{~b} 1)$ & 1.4464 & 0.1571 \\
\hline $\begin{array}{l}\text { Technological support (machinery and equipment; systems and working } \\
\text { methods) }\end{array}$ & $-0.2618(\mathrm{~b} 2)$ & -1.3601 & 0.1827 \\
\hline Qualified industrial labor & $\mathbf{0 . 3 2 3 3}(\mathbf{b 3})$ & 2.7789 & 0.0088 \\
\hline Industrial efficiency level & $0.3970(\mathrm{~b} 4)$ & 2.1712 & 0.0369 \\
\hline Small Companies location. & 0.0773(b5) & 0.6751 & 0.5042 \\
\hline Preservation of the industry's local environment & $0.0550(\mathrm{~b} 6)$ & 0.7674 & 0.4481 \\
\hline
\end{tabular}

Source: Polary (2012). 
By the regression equation, $\mathrm{p}<0.0001$. Multiple determination coefficient $(\mathrm{R} 2 \mathrm{xy})=$ 0.4173. Multiple correlation coefficient $(\mathrm{Rxy})=0.6460$ (Substantial positive correlation)

Conclusion: $\mathrm{F}$ is significant for $\mathrm{p}<0.0001$, at least one of the Independent variables (Peditoras) influences the Dependent variable; The coefficient of determination means that $41.73 \%$ of the $\mathrm{Y}$ variation can be explained by the model, the remaining ones (58.27\%) are inexplicable and due to other factors or chance; The variable that has the lowest $\mathrm{p}$ value is "the Qualified industrial labor one", therefore it is the one that most explains the Y variation.

These results showed the effectiveness of the ISA, as a management and innovation technology, through its variables, components and dimensions, in the management, success and perennity of MSCs, in the view of managers. Thus, it was perceived to be relevant the continuity of application of the ISA model in both private and public organizations. Therefore, the ISA model was adjusted in 2014 for public organizations (Polary, 2014), adapting specific variables that could be measured when applied to public administration.

Thereby, a survey was carried out in five public hospitals and two public universities, one federal and the other state, on "Professional Public Management and Management with People: an alternative of viable organizational excellence for public organizations" (Polary \& Silva, 2015), with the objective of evaluating the relevance of the variables of the ISA model (as it is a professional management alternative for Public Administration), in the organizational excellence of these organizations, as shown in table 26.

Table 26 - Variables of the ISA model that most favorably influence the organizational excellence of public organizations

\begin{tabular}{lcccc}
\hline \multicolumn{1}{c}{ Variables } & Average & Minimum & Maximum & $\begin{array}{c}\text { Standard } \\
\text { deviation }\end{array}$ \\
\hline Managerial competencies and skills of managers, & 9,000 & 7 & 10 & 1,195229 \\
Professional Management - ISA. & 7,625 & 7 & 8 & 0,517549 \\
Feasibility Study: technical, political, social and financial. & 7,375 & 6 & 10 & 1,407886 \\
Technology and innovation. & 8,625 & 8 & 10 & 0,744024 \\
Level of efficiency and effectiveness of results. & 7,375 & 5 & 10 & 1,505941 \\
Public Policies of the Federal, State and Municipal & 8,625 & 6 & 10 & 1,59799 \\
Government. & 8,625 & 6 & 10 & 1,407886 \\
Legality, control and transparency. & 8,375 & 6 & 10 & 1,30247 \\
Partnerships: Political-Institutional, Public-Private and & 8,000 & 6 & 10 & 1,511858 \\
Civil Society. & 7,250 & 6 & 8 & 1,035098 \\
Institutional and managerial public development. & 7,875 & 5 & 10 & 1,642081 \\
Qualification, performance and results of civil servant. & 9,125 & 8 & 10 & 0,991031 \\
Resource Training: internal and external. & & & & \\
Environmental Sustainability. &
\end{tabular}

Source: Polary and Silva (2015). 
By analyzing the data in table 26, It was found that among the 12 variables of the ISA, the "relevance to society" variable was the one with the highest average $(9,125)$, followed by the variables "Managerial competencies and skills of managers, professional management ISA" (9,000), "Level of efficiency and effectiveness of results", "Legality, control and transparency" and partnerships: political-institutional, public-private and civil society, which obtained equal averages (8.625), are those that most influence the organizational excellence of public organizations in the sample. The variable "Capacity Building: internal and external" was the one with the lowest average $(7,250)$.

As for the technological contribution, an instigating finding is that a public hospital that is a reference in health care and has high quality equipment does not have an efficient broad technology management system yet, as it was verified that the internal control systems are not the best ones in quantitative terms to supply the demand. Therefore, It lacks equipment, systems and working methods in some sectors. The variable technology and innovation in the organizations sample was evident in the view of managers to be desired by many of them, however it still needs investments in technology and innovation related to organizational development, as shown in figure 4.

Figure 4 - Technology and Innovation of the public organizations sample in Sao Luis - MA

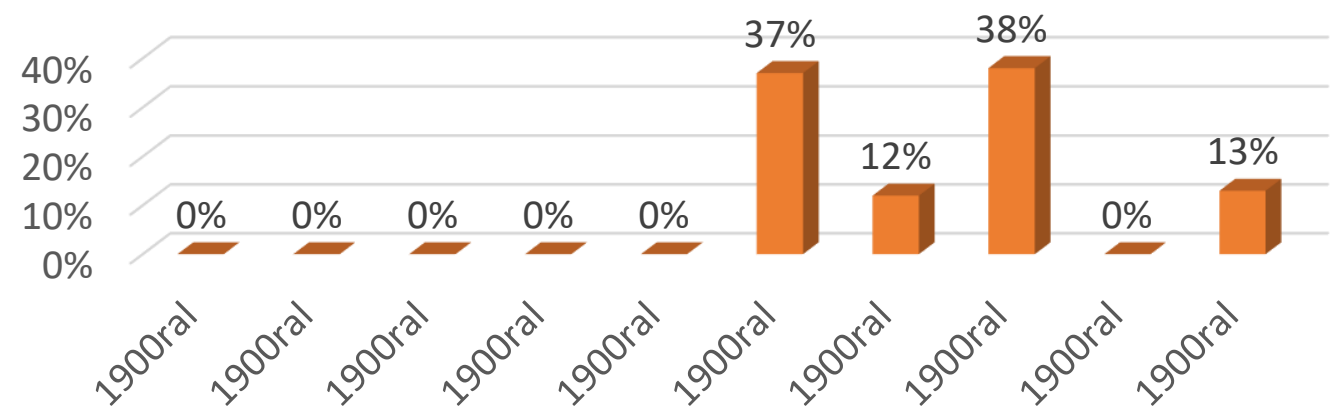

Source: Polary and Silva (2015).

On the other hand, when observing the reality in 2020 of the variable "technology and innovation" in public hospitals and universities in the sample, It is pointed out that there is an expansive growth in investments in technology and innovation in the last five years, both in terms of the dimensions and components of technological capacity, as well as in management technologies, in which these organizations have specific areas of Information Technology and qualification and development programs for managers, civil servants and even for the target audience, such as universities for the student staff. 
Among the major contributions of public organizations in the sample to the fulfillment of the mission in the State of Maranhao, in the view of the managers, respectively predominated: relevance to society, satisfaction of external customers, employee satisfaction (civil servants) and organizational excellence of services, as shown in the figure 5.

Figure 5 - Greater contributions from public institutions to fulfill the mission in the State of Maranhao

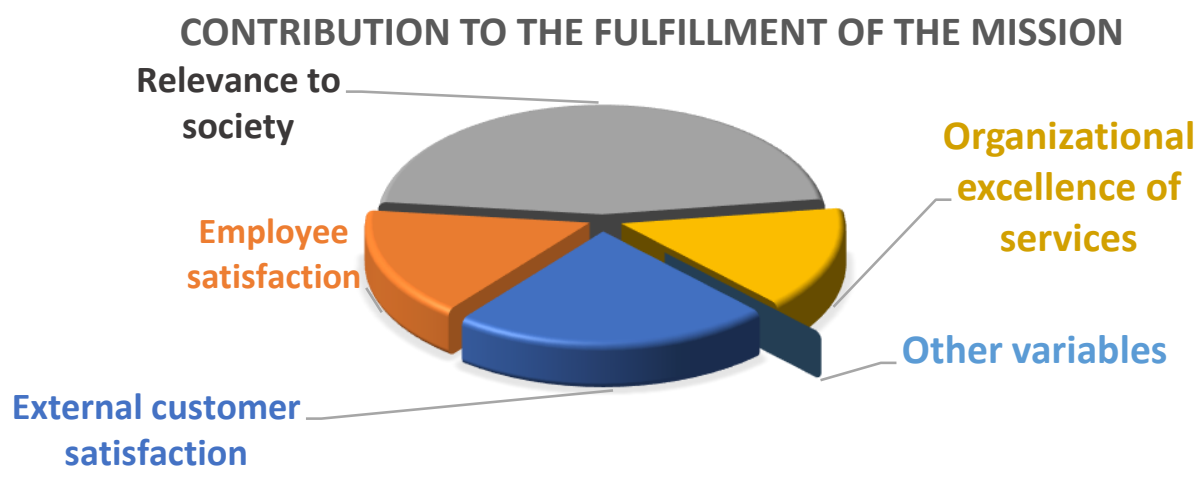

Source: Polary and Silva (2015).

In another research in MCs and SCs in the industrial and service sectors in Sao Luis of Maranhao, on Contemporary Administration Technologies, among them, the ISA (Polary et al., 2016), the results were presented.

Regarding the time of existence in the market, $64 \%$ of MCs are in the range from 1 to 4 years; $9 \%$ between 5 to 8 years; $18 \%$ between 9 to 12; and $9 \%$ over 12 years (figure 6 ).

Figure 6 - Time of existence in the market - TEM of Small Companies-SCs

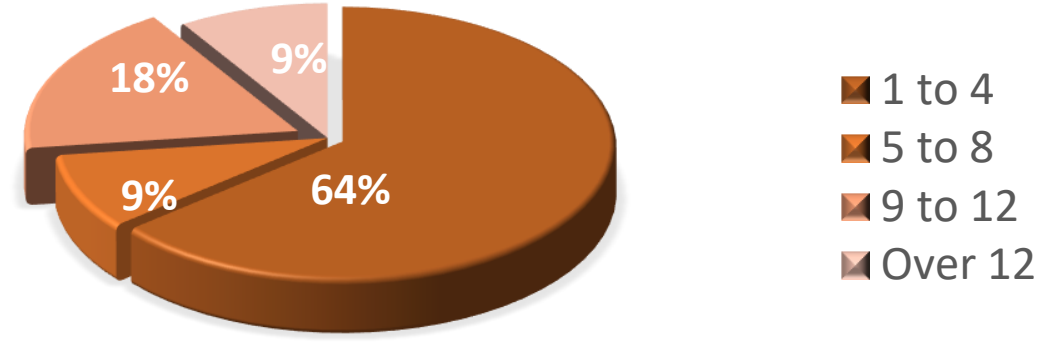

Source: Polary et al. (2016)

It is observed that less than half of the MCs in the sample have more than 4 years of market, this time of existence, based on the literature, indicates that micro companies have already passed the stage of invested capital from their opening and are in the maintenance or maintenance and growth phase. For micro companies that have existence in the market (TEM) up to four, it is 
suggested that they are in the stage of recovering the invested capital. It is noteworthy that these MCs are generally consolidating their structures and have a greater lack of technologies, which points out as an attention factor for managers on technological changes.

In analogy to the phases of MSCs (Polary, 2012), most MCs (45\%) are in the stable maintenance phase; $23 \%$ in growth phase; $23 \%$ keeping working to recover the invested capital; and $9 \%$ acquired financial stability with investments in several areas, as shown in figure 7 below.

Figure 7 - Phases of MCs in the sample
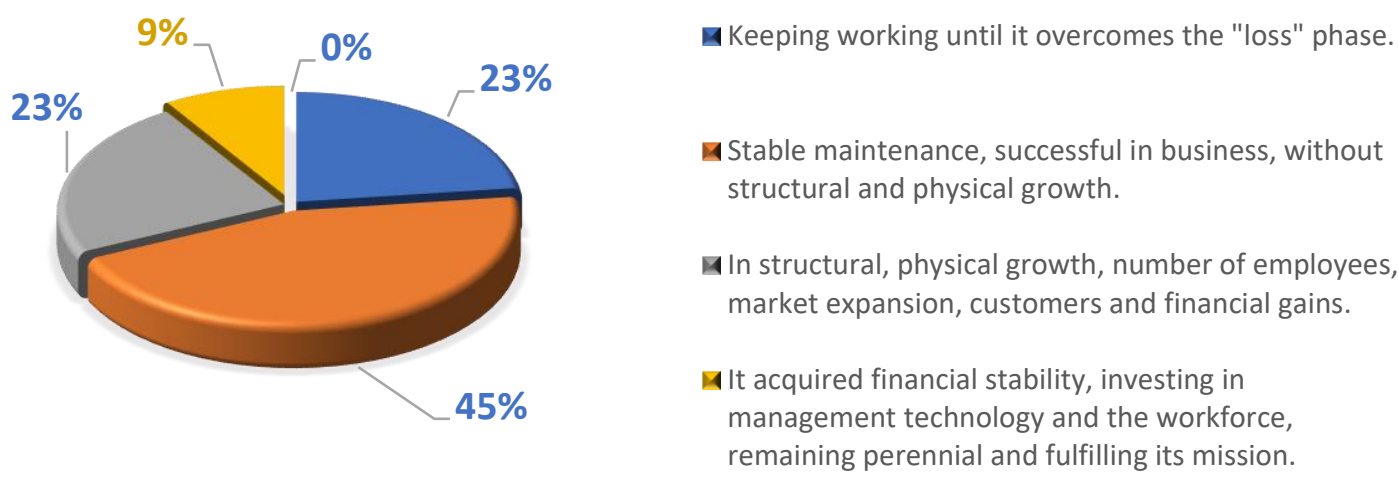

Source: Polary et al. (2016).

In SCs, the results on time and TEM (figure 8), points out that half of the SCs are over 12 years old, which can mean a certain experience related to business management, with regard to technologies. $25 \%$ have up to 4 years in the market, $19 \%$ between 5 and 8 years and $6 \%$ represent companies with 9 to 12 years in the market.

Figure 8 - TEM of SCs
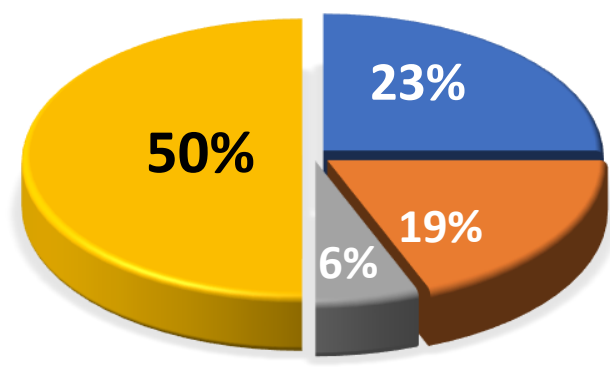

1 to 4

田 5 to 8

19 to 12

G Over 12

Source: Polary et al. (2016)

In analogy to the phases of MSCs (Polary, 2012), 63\% are in the stable maintenance phase, successfully in business, without structural and physical growth"; $31 \%$ in the phase of growth, structural, physical, customers and financial gains; and 6\% acquired financial stability, 
with investment in management technology and workforce, remaining perennial and fulfilling its mission, as shown in figure 9.

Figure 9 - Small Companies Stages - SCs

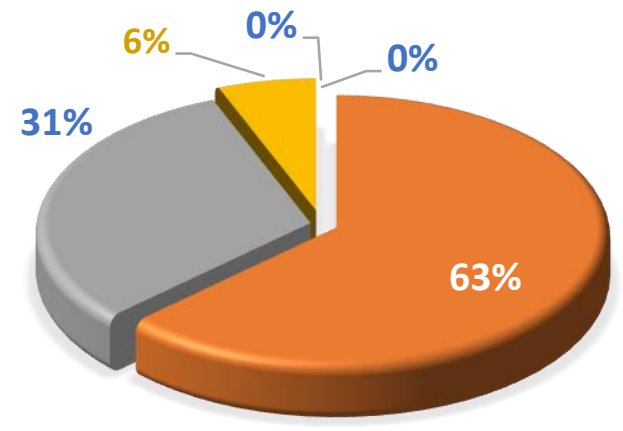

Source: Polary et al. (2016)
Keeping working until it overcomes the "loss" phase.

⿴囗十 Stable maintenance, successful in business, without structural and physical growth.

In structural, physical growth, number of employees, market expansion, customers and financial gains.

It acquired financial stability, investing in management technology and the workforce, remaining perennial and fulfilling its mission. Ending its activities in the market, after fulfilling its legal, tax and labor obligations for not wanting to continue in the business.

Regarding the relevance of the variables of the ISA, in MCs, the variables that had the best averages, in the view of managers, were preservation of the environment (8.18); business location (8.13); technological contribution on systems and working methods (7,95); level of industrial efficiency as appropriate use of production inputs $(7,77)$; legal, tax and labor aspects $(7,77)$ and qualified labor $(7,68)$. In small companies - SCs, the most relevant ISA variables were: location of the business $(8,68)$; technological contribution by machinery and equipment $(8,37)$; managerial skills and abilities - Professional Management (ISA) of partners and others who manage the business, based on Entrepreneurship $(8,18)$; technological contribution by systems and work methods $(8,18)$; level of industrial efficiency - adequate use of production inputs $(7,9)$ and Preservation of the environment $(7,75)$, according to tables 27 and 28.

Table 27 - The 06 variables of the ISA model predominant for the perennity of the MCs of the sample, in the view of the managers

\begin{tabular}{|c|c|}
\hline Variables & Average \\
\hline Preservation of the environment & 8,18 \\
\hline Business location ............................. & 8,13 \\
\hline Technological support: systems and working methods ................... & 7,95 \\
\hline Industrial efficiency level (adequate use of production inputs). & 7,77 \\
\hline 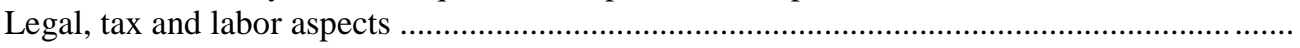 & 7,77 \\
\hline Qualified labor & 7,68 \\
\hline
\end{tabular}

Source: Polary et al. (2016). 
Table 28 - The 06 variables of the ISA model predominant for the perennity of Small Companies -SCs in the sample, in the view of managers

\begin{tabular}{|c|c|}
\hline Variables & Average \\
\hline 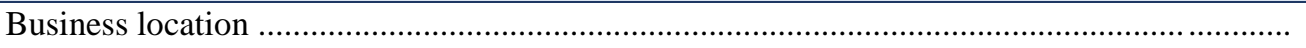 & 8,68 \\
\hline 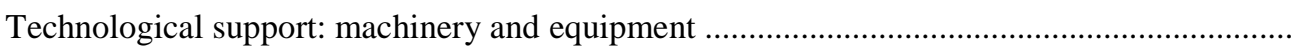 & 8,37 \\
\hline $\begin{array}{l}\text { Managerial skills and abilities - Professional Management - ISA of the partners and others } \\
\text { who manage the business, based on Entrepreneurship }\end{array}$ & 8,18 \\
\hline 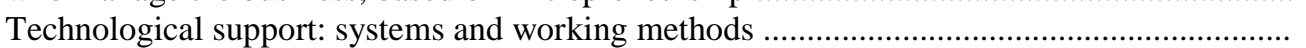 & 8,18 \\
\hline Industrial efficiency level (adequate use of production inputs). & 7,9 \\
\hline Preservation of the environment & 7,75 \\
\hline
\end{tabular}

Source: Polary et al. (2016).

As for the technology variables of the ISA model present in the MCs and SCs that contribute the most to perennity, "Products and services" predominated, with averages of 8.75 and 8,36; and as to the "importance of managers having "knowledge and experience in the area in which they operate and seek their development" to work in MCs and SCs", the results showed that for MCs and SCs managers the average was 8.27 and 9.06, respectively.

These data corroborate with the results of the survey carried out in industrial MSCs in 2012 (Polary, 2012), and suggest the continued application of the ISA model in private and public organizations, since Professional and Sustainable Management is one of the viable paths of organizational development.

\section{Conclusions}

It was verified by the literature analysis and field research that keeping micro and MSCs and public organizations in continuous, perennial and competitive organizational development in Brazil is a challenge, as well as in emerging countries, but significant progress has been noted by governments and the private sector in adopting policies to strengthen MSCs and the effectiveness of public organizations.

Regarding the phases and processes of the MSCs (Polary, 2012), it is concluded that there are other classifications in the literature with coherent thinking among the authors, in which the following ones stand out: Adizes (1998) "Life cycles of organizations: how and why do companies grow and fail and what to do about that?", and Silva et al. (2010) "Life cycle of organizations: signs of longevity of micro and small industries in Contagem-MG". As for the management, success and perennity aspects of MSCs in the Brazilian context and in some countries, it is concluded that they are all relevant, in spite of recognizing the economic and social importance that they exert for the economy of the countries, like Japan (Ilda, 1984). 
By analyzing the world and Brazilian panorama of entrepreneurship, It is concluded by its definition that "any attempt to create a new business or new enterprise, or the expansion of an existing enterprise by an individual, groups of individuals or by already established companies" its importance for the managerial development of the country.

Among the results of field research in industrial MSCs (Polary, 2012), two conclusions are relevant in the view of managers: the management of MSCs, when applied to the ISA, it favors the success and perennity of the MSCs sample; and the perennity of MSCs, positively impacts the industrial development of the State of Maranhao.

It was verified that among the 12 variables of the ISA model, in the view of managers, "Management skills and abilities of the partners who manage and those who administer or advise the business - Professional Management", it was the predominant variable that favors the management, success and perennity of MSCs; and among the 06 predominant ones, technological contribution (machinery and equipment; systems and working methods), was the second variable in order of importance for favoring management, success and perennity of MSCs; and by the correlation test, there was a predominance of substantial and moderate positive correlation among the variables, as "Technological support".

Related to the results of the research in public hospitals and universities (Polary \& Silva, 2015), it is concluded that the variables of the ISA model "relevance to society"; "Managerial competencies and skills of managers, professional management - ISA"; "level of efficiency and effectiveness of results"; "Legality, control and transparency"; and "partnerships: politicalinstitutional; public-private and civil society", were the ones that most favorably influenced the excellence of results in the public organizations in the sample.

The conclusions of the research in MCs and SCs (Polary et al., 2016), application of the ISA model, as one of the technologies of contemporary Administration, revealed that among the 06 predominant variables in the MCs, technological contribution: systems and methods of work, and level of industrial efficiency obtained the third and fourth positions; and in SCs, technological contribution: machinery and equipment, and managerial skills and abilities Professional Management - ISA of partners and others who manage the business, based on Entrepreneurship, obtained the second and third positions, as the variables that most contribute to the perennity of MCs and SCs.

These findings in industrial MSCs, hospitals and public universities, industrial MCs and SCs and service delivery researched, suggest that the ISA, as a management technology, 
combined with the dimensions and components of technological capacity, are factors of success and organizational development of MSCs and public organizations.

It is believed that these factors associated with investments in Information Technology - IT (Lunardi et al., 2017) and other digital tools, such as Business Intelligence (BI) applied in the health area (Mai et al., 2017), make MSCs and public organizations more competitive, sustainable and effective in offering products and providing services to their target audience and satisfying society.

Therefore, within the limitations of the field research, it points out "delimitation of the theoretical support study criterion in the Brazilian universe of the MSCs and public organizations", due to the fact that the country has a vast territorial dimension, lacking precise and specific data by segment (Industrial and Services delivery), which would allow a comparative analysis of how much these two segments represent in the Brazilian GDP, thus it was limited to the State of Maranhao, in the universe of its 217 municipalities (IBGE, 2009) to the MSCs and in Sao Luis, to public organizations. Aware of the pre-established limitations, it was found that the method was adequate and acceptable to support the research and consistently evaluate this topic. Thus, it was found that the research objectives were achieved, responding to the problem and verifying the hypothesis.

Every research leaves gaps so that its findings and hypotheses can be refuted sooner or later, and/ or other gaps discovered, added and adapted, as this is the basic principle of Sciences. Thus, among the research recommendations for future investigation, we highlight:

a) The continuity of ISA model application in other MSCs and public organizations, intervening with the variables that were predominant in favoring management, long-term success and perennity of the organizations in the sample, aiming to evaluate the effectiveness of the ISA in the results of these organizations in terms of organizational development and market competitiveness in medium and long term;

b) Investigate in the industrial MSCs of the sample, the determinants of the predominance of the TEM verified in the range of 14 to 23 years, as well as those of an MC identified with 83 years, and the general average of TEM for all industrial sizes of 27, 63 years, since they are above the average in comparative terms with data from the Brazilian average verified in the literature, in order to enable new discoveries that favor the management, success and perennity of companies; and

c) Expand the discussion of these results with industrial entrepreneurs in partnerships with the Serviço Nacional de Aprendizagem Industrial - National Industrial Apprenticeship Service (SENAI) and other support bodies for MSCs in Brazil, with public managers and the 
academic community, for the purpose of enabling the advancement of the concepts and theories of Sustainable Professional Management for the teaching of Administration in academia and application in private and public organizations;

The organizational development of MSCs and public organizations through innovation, management technologies, dimensions and components of technological capacity, generates regional and national development, creating possibilities for competitiveness in the global market, as It is already the reality in developed countries. Strengthen Brazilian MSCs and create conditions in public management of the three branches of government: Federal, State and Municipal levels, suggests possibilities for advancing results in terms of productivity with efficiency, quality in the provision of public services and satisfaction of society.

The expectation is that these results and conclusions will contribute to new research on the theme of innovation and technologies, focused on Sustainable Professional Management to expand discussions and debates in academia, in organizations and with other social actors.

\section{Referências}

Adizes, I. (1998). Os ciclos de vida das organizações: como e por que as empresas crescem e morrem e o que fazer a respeito? ( $4^{\mathrm{a}}$ ed.). Pioneira.

Altillo. (2020). Universidades do Maranhão: listas de universidades privadas e federais/estaduais do Estado do Maranhão. https://www.altillo.com/pt/universidades/brasil/estado/maranhao.asp.

Baggio, A.F., \& Baggio, D.K. (2014). Empreendedorismo: conceitos e definições. Revista de Empreendedorismo, Inovação e Tecnologia, 1(1), 25-38.

Bell, M., \& Pavitt, K. (1995). The development of technological capabilities. In I. Hague, M. Bell, C. Dahlman, S. Lall, \& K. Pavitt. Trade, technology and international competitiveness, pp. 69-102. World Bank.

Dornelas, J.C.A. (2008). Empreendedorismo corporativo: como ser empreendedor, inovar e se diferenciar na sua empresa ( $2^{\mathrm{a}} \mathrm{ed}$.). Elsevier.

Dosi, G. (2006). Mudança técnica e transformação industrial: a teoria e uma aplicação à indústria dos semicondutores (C.D. Slak, Trad.). Editora da Unicamp.

Drucker, P.F. (2002). Fator humano e desempenho. Pioneira Thompson Learning. Federação das Indústrias do Estado do Maranhão [FIEMA]. (2006). Cadastro industrial de São Luís-MA. FIEMA.

Figueiredo, P.N. (2003). Aprendizagem tecnológica e performance competitiva. Fundação Getúlio Vargas. 
Figueiredo, P.N. (2004). Aprendizagem tecnológica e inovação industrial em economias emergentes: uma breve contribuição para o desenho e implementação de estudos empíricos e estratégias no Brasil. Revista Brasileira de Inovação, 3(2), 323-362.

Global Entrepreneurship Monitor [GEM]. (2019). Empreendedorismo no Brasil: 2019 (S.M.S.S. Greco, Coord.). IBQP.

Greco, S.M. (2008). Entrepreneurship in Brazil. IBQP.

Greco, S.M. (2010). Entrepreneurship in Brazil. IBQP.

Hood, C. (1995). The "new public management" in the 1980s: variations on a theme. Accounting, Organizations and Society, 20(2/3), 93-109.

Ilda, I. (1984). Pequena e média empresa no Japão. Brasiliense.

Instituto Brasileiro de Geografia e Estatística [IBGE]. (2012). Síntese de indicadores sociais: uma análise das condições de vida da população brasileira. IBGE.

Junta Comercial do Maranhão [JUCEMA]. (2016). Estatístico do cadastro: microempresa e empresas de pequeno porte. SINREM.

Katz, J. (2003). The chronology and intellectual trajectory of American entrepreneurship education 1876-1999. Journal of Business Venturing, 18(2), 283-300.

Kim, L. (2005). Da imitação à inovação: a dinâmica do aprendizado tecnológico da Coreia (M.P.G.D. Rocha, Trad.). Unucamp.

Lakatos, E.M., \& Marconi, M.A. (2007). Metodologia científica (7 $7^{\mathrm{a}}$ ed.). Atlas.

Lall, S. (1992). Technological capabilities and industrialization. World Development, 20(2), $165-186$.

Lumpkin, G.T. \& Dess, G.G. (1996). Clarifying the entrepreneurial orientation construct and linking it to performance. Academy of Management Review, 21(1), 135-172.

Lunardi, G.L., Dolci, D.B., \& Dolci, P.C. (2017). Adoção de tecnologia da informação e sua relação com a gestão de negócios em micro e pequenas empresas (MPEs). Revista de Administração, 10(5), 929-948.

Mai, S., Guimarães, C.F., Silva, J.M., \& Hinkel, J.H.S. (2017). O uso das tecnologias na democratização da informação em Saúde. Revista de Gestão em Sistemas de Saúde, 6(3), 210-218.

Malhotra, N. (2006). Pesquisa de marketing: uma orientação aplicada (4ª ed.). Bookman.

McClelland, D.C. \& Winter, D.G. (1970). Como se motiva el exito economico. Unión Gráfica. 
Nelson, R. \& Winter, S. (2005). Uma teoria evolucionária da mudança econômica (C. Heller, Trad.). Editora da Unicamp.

Oliveira, D.L., Silva, T.F., Gouveia Neto, S.C., Porto, W.S., Zaidan, F.H. (2014). Fatores de decisão para investimento em tecnologia da informação nas micro e pequenas empresas. Gestão Contemporânea, 15, 55-86.

Paes-Paula, A.P. (2005). Administração pública brasileira entre o gerencialismo e a gestão social. Revista de Administração de Empresas, 45(1), 36-49.

Paula, A.P.P. (2005). Por uma nova gestão pública: limites e potencialidades da experiência contemporânea. FGV.

Penrose, E.T. (1959). The theory of growth of the firm. Brasil Black Well.

Polary, I. (2012). Gestão por sustentabilidade integrada-GSI: uma análise nas Micro, Pequenas, Médias e Grandes Empresas (MPMGEs), a partir da Literatura e da visão dos Gestores Industriais do Estado do Maranhão. Tese de Doutorado não publicada, Escola Brasileira de Administração Pública e de Empresas da Fundação Getúlio Vargas.

Polary, I. (2014). Gestão pública profissional e gestão com pessoas: uma alternativa de excelência organizacional viável para as organizações públicas. Projeto PIBICCNPQ/UEMA/FAPEMA - Ed. N 07/2014 não publicado. Universidade Estadual do Maranhão.

Polary, I. (2016). Gestão pública integrada: aplicação da gestão profissional empreendedora - GPE nas organizações públicas. Artigo apresentado na $18^{\circ}$ Encontro Internacional sobre Gestão Empresarial e Meio Ambiente 2016, São Paulo, Brasil.

Polary, I. (2019). Gestão por Sustentabilidade Integrada - GSI: uma alternativa de gestão profissional para as organizações. Appris Editora.

Polary, I., \& Silva, F. (2015). Gestão Pública Profissional e Gestão com Pessoas: uma alternativa de excelência organizacional viável para as Organizações Públicas. Relatório final do Projeto PIBIC-CNPQ/UEMA/FAPEMA - Ed. Nº 07/2014 não publicado. Universidade Estadual do Maranhão.

Polary, I., Ramos, A., Silva, Y., \& Silva, A. (2016). As contribuições das tecnologias da Administração e perenidade das Micro e Pequenas Empresas-MPEs. Relatório final do projeto de extensão selecionado PIBEX - Ed. Nº6/2015-PROEXAE/UEMA não publicado. Universidade Estadual do Maranhão.

Quivy, R., \& Campenhoudt, V. L. (1995). Manual de investigação em ciências sociais (2a ed.). Gradativa Publicações.

Schumpeter, J.A. (1934). The theory of economic development. Harvard University Press.

Secretaria Municipal de Saúde [SEMUS]. (2021). Guia de Unidades de Saúde. https://www.saoluis.ma.gov.br/semus/conteudo/1771. 
Silva, W.A.C., Jesus, D.K.A., \& Melo, A.A.O. (2010). Ciclo de vida das organizações: sinais de longevidade de micro e pequenas indústrias na região de Contagem-MG. Revista de Gestão, 17(3), 245-263.

Teece, D. \& Pisano, G. (1994). The dynamic capabilities of firms: an introduction. Industrial and Corporate Change, 3(3), 537-556.

Triviños, A.N.S. (2009). Introdução à pesquisa em ciências sociais: a pesquisa qualitativa em educação. Atlas.

Ulrich, D., Smallwood, N., \& Sweetman, K. (2009). O código da liderança. Best Seller.

Universidade Estadual do Maranhão [UEMA]. (2016). Plano de Desenvolvimento - PDI 2016-2020. UEMA/PROPLAN. 